
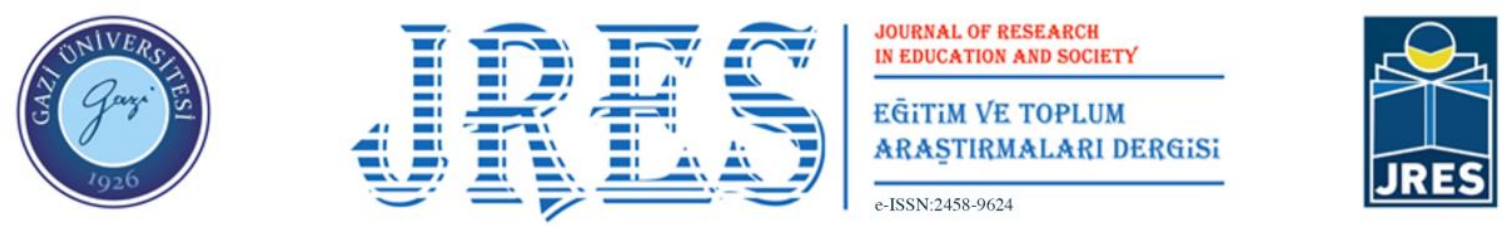

Cilt: 8 Sayı: 1 Sayfa Aralığı: 205-227 e-ISSN: 2458-9624 DOI: 10.51725/etad.940163

\title{
İşbirlikli Öğretim Yönteminin Türkçe Dersinde Akademik Başarı, Motivasyon ve Öğrenme Kalıcılığı Üzerindeki Etkisinin Belirlenmesi*
}

Determining the Effect of Cooperative Teaching Method on Academic Achievement, Motivation and Learning Retention in Turkish Lessons

\section{Aysel Arslan, Ali Osman Engin}

\section{ÖZ}

Bu çalışmanın amacı; Türkçe Dersi (1-8. Sınıflar) Öğretim Programı 7. Sınıf Kazanımlarında kullanılan İşbirlikli Öğretim Yöntemi içinde yer alan Birleştirilmiş İşbirlikli Okuma ve Kompozisyon, Öğrenci Takımları Başarı Bölümleri ve Jigsaw II tekniklerinin öğrencilerin akademik başarıları, Türkçe dersine yönelik öğrenme motivasyonları ve öğrenme kalıcılıkları üzerindeki etkisini belirlemektir. Araştırmanın verilerinin elde edilmesinde ön test-son test kontrol gruplu yarı deneysel desen kullanılmıştır. Araştırmanın çalışma grubunu 2019-2020 eğitim-öğretim yılında ortaokul 7. sınıfta dört farklı şubede öğrenimlerine devam eden 83 öğrenci oluşturmuştur. Üç şubede işbirlikli öğrenme teknikleri bir şubede ise mevcut öğrenme programı uygun olarak dersler işlenmiştir. Araştırma verilerinin elde edilmesinde Akademik Başarı Testi ve Türkçe Dersine Yönelik Motivasyon Ölçeği kullanılmıştır. Verilerin analizinde tanımlayıcı istatistikler, ANOVA, bağımlı gruplar $\mathrm{t}$ testi uygulanmıştır. Araştırma sonuçlarına göre; öğrencilerin akademik başarıları, öğrenme motivasyon ve kalıcılık puanlarının araştırma grupları arasında işbirlikli tekniklerin uygulandığı gruplar lehine olmak üzere istatistiksel olarak anlamlı düzeyde farklılık gösterdiği belirlenmiştir.

\footnotetext{
ABSTRACT

The aim of this study; is to determine the effects of Cooperative Integrated Reading and Composition, Student Teams-Achievement Divisions and Jigsaw II techniques, which are included in the Cooperative Teaching Method used in the 7th grade Turkish Lesson Curriculum, on students' academic achievement, learning motivation for Turkish lesson and learning retention. A pretest-posttest control group quasi-experimental design was used to obtain the data of the study. The study group of the research consisted of 83 students who were continuing their education in four different branches in the 7th grade of secondary school in the 2019-2020 academic year. Cooperative learning techniques were taught in three branches and lessons were taught in accordance with the current learning program in one branch. Academic Achievement Test and Motivation Scale for Turkish Lessons were used to obtain research data. Descriptive statistics, ANOVA, dependent groups $t$ test were used to analyze the data. According to the results of the research; it was determined that the students' academic achievement, learning motivation and retention scores differed statistically significantly among research groups in favor of the groups in which cooperative techniques were applied.
}

Yazar Bilgileri Aysel Arslan iD

Öğr. Gör. Dr., Sivas

Cumhuriyet Üniversitesi, Sivas,

Türkiye

ayselarslan@cumhuriyet.edu.tr

Ali Osman Engin (iD

Prof. Dr., Atatürk Üniversitesi,

Erzurum, Türkiye

aliosman.engin@atauni.edu.tr

\begin{tabular}{r} 
Makale Bilgileri \\
\hline Anahtar Kelimeler \\
İşbirlikli öğretim \\
Türkçe dersi \\
Öğrenme motivasyonu \\
Tutum \\
Kalıcılık \\
Keywords
\end{tabular}

Cooperative teaching

Turkish lesson

Learning motivation

Attitude

Retention

Makale Geçmişi

Geliş: 20/05/2021

Düzeltme: $12 / 06 / 2021$

Kabul: $14 / 06 / 2021$ Atıf için: Arslan, A. ve Engin, A. O. (2021). İşbirlikli öğretim yönteminin türkçe dersinde akademik başarı, moti
ve öğrenme kalıcılığı üzerindeki etkisinin belirlenmesi. JRES, 8(1), 205-227. https://doi.org/10.51725/etad.940163 Etik Bildirim: Bu çalışma doktora tezinden üretilmiş olup 01.01 .2020 tarihinden önce yapıldığından etik kurul kararı zorunluluğu yoktur.

\footnotetext{
* Bu makale; Prof. Dr. Ali Osman ENGİN danışmanlığında, Aysel ARSLAN tarafından 2021 yılında tamamlanan “Türkçe Öğretim Programında İşbirlikli Öğretim Yönteminin Akademik Başarıya, Öğrenme Motivasyonuna, Tutum ve Kalıcılığa Etkisi" isimli doktora tezinden türetilmiştir.
} 


\section{Giriş}

Türkçe dersi öğretim programlarının (TÜDÖP); Türkçenin anlatım gücünü, söz varlığını, yapı ve ses özelliklerini, anlam zenginliğini öğrencilere etkin ve doğru olarak aktarılmasını sağlayacak şekilde hazırlanması oldukça büyük önem arz etmektedir (Aksan, 2017). Ülkemizde Türkçe dersine yönelik olarak hazırlanan TÜDÖP’ler, uzun yıllar davranışçılık yaklaşımına göre hazırlanırken, 2005 yılında yapılandırmacılık eğitim yaklaşımının benimsenmesiyle bu yaklaşıma uygun yöntem ve teknikleri içerecek şekilde hazırlanmaya başlanmıştır. Yapılandırmacılık felsefesine uygun olarak süreç içerisinde; öğrencilere elde etmeleri gereken bilgiyi nereden ve nasıl ulaşacaklarını, karşılaştıkları sorunlar karşısında nasıl bir çözüm yolu izlemeleri gerektiğini öğretmek amacıyla sınıf içi ve sınıf dışında kullanılabilen çeşitli model, yöntem ve teknikler geliştirilmiştir (Tarım ve Akdeniz, 2008). Bu yaklaşım ve yöntemlerin bazıları; İşbirlikli Öğrenme/ İşbirlikli Öğretim, Çoklu Zekâ, Proje Tabanlı Öğrenme, Probleme Dayalı Öğrenme (Bayrakçeken, Doymuş ve Doğan, 2013) ve Aktif Öğrenme'dir (Açıgöz, 2004). İşbirlikli öğretim; öğrencilerin daha önceden uzmanlar tarafından belirlenen ortak öğrenme amaçlarını gerçekleştirmek için 2-6 arasında değişen sayıdaki küçük gruplar halinde birlikte çalıştıkları (Açıkgöz, 2016); konu, içerik ve kavramları üst düzeyde anlayarak öğrendikleri, grup içindeki arkadaşlarıyla kendi öğrendiklerini paylaştıkları (Doymuş, Şimşek ve Bayrakçeken, 2004); aktif ve etkin öğrenmeye, birlikte çalışmaya dayalı bir yöntem olarak tanımlanmıştır (Gözütok, 2007). İşbirlikli öğretimi Slavin (1990), grup halindeki öğrencilerin öğretmenin hazırladığı farklı materyalleri kullanarak uzmanlaştıkları; Johnson ve Johnson (1999), öğrencilerin hem kendi hem de arkadaşlarının öğrenmelerini mümkün olan en üst seviyeye çıkarmak amacıyla birlikte çalıştıkları birbirleriyle etkileşim kurarak geri bildirimlerle daha derinlemesine öğrenmelerinin sağlandığı bir yöntem şeklinde ifade etmiştir. Genel olarak yapılan tanımlara bakıldığında işbirlikli öğretimin öğrencilerin gruplar halinde birlikte çalıştıkları, birb,irlşerinin öğrenmesine yardım ederken kendi öğrenmelerini de üst düzeye çıkardıkları, iletişim ve etkileşimin üst düzeyde olduğu bir öğretim yöntemi olduğu görülmektedir.

İşbirlikli öğretim yönteminin temelini oluşturan grup çalışmaları, geleneksel modellerdeki basit yapılı küme çalışmalarıyla kesinlikle karıştıılmamalıdır (Açıkgöz, 2016). Burada önemli olan ve işbirlikli öğretimi sıradan bir küme çalışmasından ayıran en önemli nokta her bir öğrencinin kendisinin ve grup arkadaşlarının öğrenme kapasitelerini sonuna kadar geliştirmek için çabalamasıdır (Johnson ve Johnson, 1990). Çalışma grupları oluşturulurken öğrencilerin heterojen bir şekilde dağılmasına dikkat edilmelidir (Watson, 1992). Bu sayede gruplardaki başarısı daha düşük öğrencilerin arkadaşlarının desteğiyle gelişmesine olanak sağlanır. Öğrencinin grup içinde başarısı arttıkça kendine olan güveni de artar. Ayrıca grup içinde arkadaşlarını daha yakından tanıma şansı bularak arkadaşlık, dostluk bağlarını geliştirir, yardımlaşmanın ve dayanışmanın önemini kavrar, empati kurmayı öğrenir (Sharan, 1999), iletişim becerileri, eleştirel düşünme ve problem çözme becerileri gelişerek özgüven duyguları artar (Ballantine ve Larres, 2007).

Kuramsal açıdan bakıldığında; işbirlikli öğretim yönteminin temelinde pek çok farklı teorinin birleştiği zengin bir yapı bulunduğu görülmektedir (Johnson ve Johnson, 1990). Bu yapıdaki en önemli teorilerin; Bandura tarafından geliştirilen Sosyal Öğrenme, Piaget tarafından geliştirilen Bilişsel Gelişim, Sosyal Bağlılık, Davranışçı Öğrenme olduğu ifade edilmektedir (Avcı ve Fer, 2004; Johnson ve Johnson, 1990). Sosyal Öğrenme Kuramı'nda davranışa dönüştürülen bilgi ve bireylerin kurdukları etkileşim önemlidir. Bireyin öğrenmesinde, toplum içindeki diğer bireylerin yaşantılarına ilişkin gözlemleri ve deneyimlerinin önemli olduğu savunulur (Değer, 2010). Bilişsel Gelişim Kuramı'na göre; farklı yaşlarda kendini ve çevresini farklı algılayan birey, çeşitli olay ve durumlara ilişkin bilgileri de 
bu alg1 perspektifinden değerlendirir. Birey, herhangi bir konuda edindiği bilgiye ek olarak sonradan öğrendiği her yeni bilgiyi öncelikle zihninde var olan eski bildikleriyle karşılaştırır. Sonrasında duruma göre öğrendiği yeni bilgilerle ya eski bilgisini geliştirir, derinleştirir ya da eski bilgisini gözden geçirerek yeniden yapılandırır (Miller, 1997). Sosyal bağlılık, işbirliğine dayalı öğrenme yaklaşımı üzerinde en çok etkisi olan teoridir (Johnson ve Johnson, 1990). Aidiyet duygusu; bireyin doğduğu andan itibaren çevresiyle sosyal/duygusal bağlar kurduğu, çevresiyle yaşadığı deneyimlerini zamanla içselleştirdiği, bu bağlllık sayesinde kendini güvenli ve rahat hissettiği (Lee ve Robbins, 1998), kendini ifade etmesinin bir yolu olarak tanımlanır. Geleneksel öğrenme modellerinin temelini oluşturan davranışçılıkta ödülceza oldukça önemlidir. Davranışçı öğrenme yaklaşımındaki bu ödül-ceza teorisi, işbirlikli öğretim yöntemindeki grup ödülünün de mantığını oluşturur (Avcı ve Fer, 2004). İşbirlikli öğrenmede yapılan grup çalışmalarında, grup üyeleri birbirlerini daha başarılı olmak için teşvik eder. Dolayısıyla bu da grubun başarısını artırır (Yılmaz, 2001).

İşbirlikli öğretim temelinde pek çok farklı teknik geliştirilmiştir. Bu tekniklerin belli başlı ortak ilkeleri vardır. İşbirlikli öğretim yönteminin sınıf içindeki uygulama sürecinde dikkat edilmesi gereken ilkeler; olumlu bağlılık, grup ödülü, yüz yüze destekleyici etkileşim, bireysel değerlendirilebilirlik, kişiler arası ve sosyal beceriler, eşit başarı fırsatı, grup süreci olarak yedi başlık altında toplanmıştır (Johnson, Johnson ve Holubec, 1994). Olumlu bağlılık bir diğer ifadeyle pozitif bağlllık işbirlikli öğretimin en önemli ilkesi, adeta kalbidir (Johnson ve Johnson, 2002). Grup üyeleri “Birlikte yüzmeyi başaramazsak batarız" düşüncesine sahip olmalıdır (Johnson ve Johnson, 1999). Grup ödülü; temeli davranışçılığa dayansa da işbirlikli öğretimde elde edilen başarılı sonuçlar için öğrencilerin grup olarak ödüllendirilmesini ifade eder (Açıkgöz, 2016). Yüz yüze destekleyici etkileşim; grupta yer alan öğrencilerin grubun başarısını yükseltmek amacıyla birbirlerine destek olmaları, güvendiklerini hissettirerek uygun yönlendirmelerde bulunmaları, birbirlerinin öğrenme çabalarını desteklemeleri, grup arkadaşlarını cesaretlendirmeleri, herkes için süreci kolaylaştırmaları, olarak ifade edilir (Johnson ve Johnson, 2002). Bireysel değerlendirilebilirlik; grup üyelerinin birlikte çalışarak öğrenmesinin yanında tek başlarına ortaya koydukları performans düzeyinin belirlenmesidir. Sonuçta grup çalışmasının asıl amacı öğrencinin öğrenmesidir (Ekinci, 2011). İşbirlikli öğrenme içinde önemli bir ilke olan kişiler arası ve sosyal beceriler; öğrencilerin grup içinde doğru ve etkili iletişim kurmalarına ilişkin becerilerinin geliştirilmesi gerekliliğini ifade eder (Açıkgöz, 2016). Eşit başarı fırsatı; işbirlikli grup çalışmasının sonunda grup bütün olarak başarılı olsa bile bazen gruptaki tüm öğrencilerin yapılan çalışmadan aynı verimi almadığı görülür (Senemoğlu, 2007). Gruptaki tüm öğrencilerin süreç sonunda etkili bir öğrenme elde edebilmesi için grup çalışmalarına aktif olarak katılması ve bildikleri her şeyi arkadaşlarıyla paylaşması (Borich, 2014), arkadaşlarının öğrenmesi içi çaba göstermesi, grup görevlerini yerine getirmesi gerekir (Slavin, 1990). Grup süreci; gruptaki öğrencilerin grubun ortaya koyduğu faaliyetlerin verimliliği, beklenilen sonuca uygunluğu vb. konularda tartışması, bireysel veya ortak değerlendirme yapması olarak tanımlanır (Johnson ve Johnson, 1999).

İşbirlikli öğretim yöntemi çerçevesinde Takım-Oyun-Turnuva, İşbirliği-İşbirliği, Birlikte Okuma ve Kompozisyon (BİK), Jigsaw, Öğrenci Takımları Başarı Bölümleri (ÖTBB), Buluş gibi birçok teknik geliştirilmiştir. Slavin'in geliştirdiği BİOK tekniği geleneksel okuma yaklaşımları temeline dayanır (Açıgöz 2004). BİOK'ta okuma ve yazma becerisine yönelik yapılan etkinliklere örnek olarak; yüksek sesle okuma, okuduklarına ilişkin tahmin etme, çıkarımlar yapma, soru sorma, okuduklarını özetleme, okuduğu metinle ilgili kompozisyon yazma vb. verilebilir (Çörek, 2006). BİOK tekniğinde genel olarak küçük grup süreci kullanılır. Grup üyelerinin gruplarının başarılı olması ve ödül alması için birbirine yardım etme zorunluluğu bulunur. Bu süreç boyunca işbirlikli öğretimin temel ilkeleri 
uygulanmış olur (Senemoğlu, 2007). ÖTBB; öğrencilerin işbirlikli çalışma tekniğini kullanarak akademik konuları daha iyi öğrenebileceği temeline dayanan (Slavin, 1999), ilköğretimin ikinci kademesindeki öğrencilerin okuma, yazma ve diğer dil becerilerinin geliştirilmesini hedefleyen kapsamlı bir teknik olarak tanımlanmaktadır (Yaman, 1999). ÖTBB, geleneksel yolla öğretilen okumayazma ve diğer dil becerilerinde karşılaşılan sorunların eğitim ortamında çözümlenmesi amacıyla planlanmıştır (Açıkgöz, 2004). Jigsaw tekniğini Eliot Aronson geliştirmiş, Slavin ise daha işlevsel olması için yeniden düzenlemiştir (Komisyon, 2014). Bu tekniğe uygun olarak geliştirilmiş Jigsaw II, Jigsaw III, Jigsaw IV, Ters Jigsaw, Konu Jigsawı olmak üzere farklı uygulamaların bulunduğu görülmektedir. Aronson (1978) tarafından geliştirilen Jigsaw tekniği ile Slavin'in (1987) geliştirdiği Jigsaw II tekniği arasında Jigsaw II'de ekip rekabetinin bulunması açısından farklılık bulunmaktadır. Alanyazın incelendiğinde BİOK, ÖTBB ve Jigsaw II teknikleriyle yapılan birçok çalışmanın yer aldığı saptanmıştır. Yaman'ın (1999) Türkçe dersinde akademik başarı, tutum ve okuduğunu anlama; Güreş'in (2008) akademik başarı; Genlott ve Grönlund'un (2013) okuma ve yazma becerileri; Gonzales ve Torres'in (2015) okuduğunu anlama, ayrıntıları hatırlama, özetleme, ana fikrin belirlenmesi, çıkarım yapma, karşı tezin oluşturulması konularındaki başarıları üzerinde BİK tekniğinin etki düzeyini araştıran çalışmalar yaptıkları belirlenmiştir. Ocak ve Küçükilhan (2014) akademik başarı ve kalıcılık; Kartal ve Özbek (2016) akademik başarı, derse yönelik tutum ve kişiler arası ilişkiler; Tiantong ve Teemuangsai (2013) bilgisayar programlama dersindeki başarı; Ahmad (2015) İngilizce çeviri becerileri; Gambari, Yusuf ve Thomas'ın (2015) akademik başarı ve motivasyon üzerinde ÖTBB tekniğinin etkisini belirlemeyi amaçlayan çalışmalar yürütmüştür. Jigsaw II ile yapılan çalışmalara bakıldığında; Baş'ın (2009) İngilizce dersindeki erişi, tutum ve öğrenme kalıcılıkları; Evcim ve İpek'in (2013) akademik başarıları; Yılar'ın (2016) sözlü anlatım becerisi; Putri'nin (2013) söz varlıklarının gelişmesi; Nurwanti, Asrifan ve Haedar'ın (2019) açıklayıcı metin okuma düzeyleri üzerindeki etkisinin belirlenmesi amacıyla çalışmalar yaptıkları görülmektedir.

Yapılan çalışmalarda genel olarak işbirlikli öğretim teknikleri kullanılarak yapılan çalışmaların amaçlarına uygun olarak öğrencilerin başarılarını ve ölçülen diğer özelliklerini mevcut yöntemle kıyaslandığında daha olumlu etkilediği görülmektedir (Karafkan ve Aghazadeh, 2015; Kim, 2018; Tabiolo ve Rogayan, 2019). Alanyazında işbirlikli öğretim teknikleriyle yapılan çalışmalarda tek bir işbirlikli öğretim tekniğinin müfredata uygun olarak uygulanan mevcut öğrenme yöntemine göre etkililiğinin araştırılmasının yanı sıra iki, üç farklı tekniğin aynı çalışma kapsamında yer aldığı da görülmektedir (Akar ve Doymuş, 2015; Zarei, 2012). Bu çalışmalarda kullanılan tekniklerin hem kullanılan mevcut yöntemle hem de birbirleri ile karşılaştırması yapılmıştır. Yapılan bazı çalışmalarda ise mevcut öğrenme yönteminin kullanıldığ gruba yer verilmemiş ve sadece farklı işbirlikli öğrenme grupları oluşturulmuştur (Baydar, 2015). Bu gruplar arasında öğrencilerin akademik başarıları ve farklı özellikleri üzerinde işbirlikli öğretim tekniklerinin etki düzeyi karşılaştırılmıştır. Ancak TÜDÖP'te; BİOK, ÖTBB ve Jigsaw tekniklerinin birlikte kullanılmasının öğrencilerin akademik başarı, tutum ve öğrenme motivasyonlarına yönelik etkisini kullanılan mevcut öğrenme yöntemine ve birbirlerine göre karşılaştırmalı olarak belirlemek amacıyla yapılan bir çalışmaya ilgili alanyazında rastlanılmamıştır. Bu çalışma; işbirlikli öğretim teknikleri arasında yer alan BİOK, ÖTBB ve Jigsaw II'nin sadece TÜDÖP'te kullanılan mevcut yönteme göre değil birbirleri ile de etkililik bakımından karşılaştırılmasını amaçlamaktadır. Bu doğrultuda yapılan bu araştırmanın alanyazına önemli katkı sağlayacağ düşünülmektedir. Çalışma kapsamında yer alan akademik başarı testi ve Türkçe dersine yönelik öğrenme motivasyonu ölçeğine yönelik sorular aşağıda verilmiştir: 


\section{Akademik Başarı Testine İlişkin Sorular}

1. Türkçe Dersi (1-8. Sınıflar) Öğretim Programı 7. Sınıf Kazanımlarında BİOK, ÖTBB, Jigsaw II teknikleri ve mevcut uygulama yönteminin uygulandığı araştırma gruplarındaki 7. sınıf öğrencilerinin "Akademik Başarı Testi"nden aldıkları ön test ve son test puanları arasında anlamlı farklılık bulunmaktadır.

2. Türkçe Dersi (1-8. Sınıflar) Öğretim Programı 7. Sınıf Kazanımlarında BİOK, ÖTBB, Jigsaw II teknikleri ve mevcut uygulama yönteminin uygulandığı araştırma gruplarındaki 7. sınıf öğrencilerinin "Akademik Başarı Testi"nden aldıkları son test puanları arasında anlamlı farklılık bulunmaktadır.

3. Türkçe Dersi (1-8. Sınıflar) Öğretim Programı 7. Sınıf Kazanımlarında BİOK, ÖTBB, Jigsaw II teknikleri ve mevcut uygulama yönteminin uygulandığı araştırma gruplarındaki 7. sınıf öğrencilerinin "Akademik Başarı Testi”nden aldıkları son test ve öğrenme kalıcılık testi puanları arasında anlamlı farklılık bulunmaktadır.

4. TÜDÖP'te BİOK, ÖTBB, Jigsaw II teknikleri ve mevcut uygulama yönteminin uygulandığ1 araştırma gruplarındaki 7. sınıf öğrencilerinin "Akademik Başarı Testi"nden aldıkları öğrenme kalıclık testi puanları arasında anlamlı farklılık bulunmaktadır.

\section{Öğrencilerin Türkçe Dersine Yönelik Motivasyonlarına İlişkin Sorular}

1. Türkçe Dersi (1-8. Sınıflar) Öğretim Programı 7. Sınıf Kazanımlarında BİOK, ÖTBB, Jigsaw II teknikleri ve mevcut uygulama yönteminin uygulandığı araştırma gruplarındaki 7. sınıf öğrencilerinin "Türkçe Dersine Yönelik Motivasyon Ölçeği"nden aldıkları ön test-son test puanları arasında anlamlı farklılık bulunmaktadır.

2. Türkçe Dersi (1-8. Sınıflar) Öğretim Programı 7. Sınıf Kazanımlarında BİK, ÖTBB, Jigsaw II teknikleri ve mevcut uygulama yönteminin uygulandığı araştırma gruplarındaki 7. sınıf öğrencilerinin “Türkçe Dersine Yönelik Motivasyon Ölçeği”nden aldıkları son test puanları arasında anlamlı farklılık bulunmaktadır.

\section{Yöntem}

Araştırmanın bu bölümünde araştırmada kullanılan model, araştrırma grubunun seçimi ve oluşturulması, kullanılan veri toplama araçları, verilerin toplanması ve analiz süreçlerine yönelik bilgiler sunulmuştur.

\section{Araştırma Modeli}

Araştırma modeli; yapılan araştırmanın tür ve amacına uygun olarak en pratik ve ekonomik şekilde araştırma verilerinin elde edilmesi, analizinin yapılması için ihtiyaç duyulan tüm koşulların sistemli bir şekilde düzenlenmesini kapsamaktadır (Karasar, 2014). Araştırmaya ilişkin veriler, ön testson test kontrol gruplu yarı deneysel desen kullanılarak elde edilmiştir. Eğitim bilimcilerin yaptıkları araştırmalarda gerçek deneysel desen yerine yarı deneysel desenin tercih edilmesi sık rastlanan bir durumdur. Bunun nedeni; araştırmanın yapılacağı okul, sınıf ve öğrencilerin tesadüfi seçiminin uygulanma şansının neredeyse olmamasıdır (Cohen, Manion ve Morrison, 2007). Karasar (2014), MEB'e bağlı bulunan okullarda yapılan araştırmalarda da benzer durumla karşılaşıldığını belirterek, grupların birbirine denk olarak oluşturulmasının çok zor olduğunu ifade etmiştir. Ön test-son test kontrol gruplu araştırma deseninin uygulaması süreci şu aşamalardan oluşmaktadır (Cohen vd., 2007; Karasar, 2014): 
Araştırma gruplarının yansızlık ilkesine dikkat edilerek atanması

$\checkmark$ Uygulama sürecinin başında verilerin elde edilmesi amacıyla araştırma gruplarına ön test ölçümlerinin yapılması

$\checkmark$ Bağımsız değişkenin sadece deney gruplarına alınması

$\checkmark$ Uygulama sürecinin sonunda verilerin elde edilmesi amacıyla araştırma gruplarına son test ölçümlerinin yapılması

$\checkmark$ Elde edilen ön test-son test ölçüm sonuçlarının karşılaştırılarak aralarında bir farklılık olup olmadığının belirlenmesi

\section{Çalışma Grubu}

Araştırmanın çalışma grubu, 2019-2020 eğitim-öğretim yılında Sivas il merkezinde bulunan iki farklı ortaokulda yer alan dört farklı şubede yedinci sınıf düzeyinde eğitim görmekte olan öğrencilerden seçilmiştir. Bu şubelerden üçü araştırmanın deney grubu, biri ise kontrol grubu olarak rastgele atanmıştır. Araştırmada üç farklı tekniğin kullanılacak olması nedeniyle üç şube deney grubu bir şube de kontrol grubu olarak belirlenmiştir. BİOK tekniğinin uygulandığı deney grubu (DB) olarak belirlenen şubede bulunan 27 öğrenciden 21 öğrenci, ÖTBB tekniğinin uygulandığı deney grubu (DÖ) olarak belirlenen şubede bulunan 27 öğrenciden 20 öğrenci, Jigsaw II tekniğinin uygulandı̆̆ deney grubu (DJ) olarak belirlenen şubede bulunan 27 öğrenciden 18 öğrenci ve mevcut öğrenme yönteminin uygulandığı kontrol grubu (KM) olarak belirlenen şubede bulunan 27 öğrenciden 24 öğrenci araştırmanın çalışma grubunu oluşturmuştur. Araştırmaya katılan tüm öğrenci ve öğretmenlerden elde edilen verilerde gizlilik ilkesi gereği katılımcıların isimleri gizlenerek kodlama yapılmıştır. Araştırmanın sonucunda elde edilen veriler doğrultusunda araştırma raporu oluşturulmuştur. Yarı deneysel desenin kullanıldığı bu çalışmada, öğrencilerin ataması yansızlık ilkesine riayet edilerek yapılmıştır. Bunun gerçekleşmesi için kullanılan ölçütler aşağıda yer almaktadır:

Tüm şubelerdeki öğrencilerin 6. sinıf genel not ortalamaları,

$\checkmark$ Tüm şubelerdeki öğrencilerin 6. sınıf Türkçe dersi genel not ortalamaları,

$\checkmark$ Tüm şubelerdeki öğrencilerin 6. sınıf birinci yarıyıl Türkçe dersi not ortalamaları,

$\checkmark$ Tüm şubelerdeki öğrencilerin 6. sınıf ikinci yarıyıl Türkçe dersi not ortalamaları,

$\checkmark$ Tüm şubelerdeki öğrencilerin akademik başarı testi, öğrenme motivasyonu ölçeği ön test puanları

$\checkmark$ Bu araştırmada yapılan Kolmogorov-Smirnov testinden elde edilen yansızlık atamasına ilişkin bulgular aşağıda Tablo 1'de sunulmuştur.

Tablo 1. Yansızlık Ölçütlerine İliş̧kin K-S Testi Sonuçları

\begin{tabular}{lccccc}
\hline Ölçütler & Gruplar & K-S & p & Çarpıklık katsayısı & Basıklık katsayısı \\
\hline \multirow{4}{*}{$\begin{array}{l}\text { 6. sinıf genel not } \\
\text { ortalamaları }\end{array}$} & DB & .162 & .156 & -.062 & -.897 \\
& DÖ & .138 & .200 & .737 & -.334 \\
& DJ & .124 & .200 & -.111 & -1.247 \\
\multirow{2}{*}{ 6. sinıf Türkçe dersi } & KM & .129 & .200 & .254 & -1.142 \\
genel not & DB & .151 & .200 & -.319 & -.786 \\
ortalamaları & DÖ & .201 & .033 & .533 & -.651 \\
& DJ & .233 & .011 & .354 & -1.517 \\
\hline
\end{tabular}




\begin{tabular}{lccccc}
\hline 6. sınıf birinci yarıyıl & DB & .141 & .200 & -.359 & -1.027 \\
Türkçe dersi not & DÖ & .150 & .200 & .341 & -.851 \\
ortalamaları & DJ & .216 & .026 & .223 & -1.661 \\
& KM & .086 & .200 & -.347 & -.520 \\
\hline \multirow{2}{*}{ 6. sınıf ikinci yarıyıl } & DB & .175 & .091 & -.225 & -1.043 \\
Türkçe dersi not & DÖ & .208 & .023 & .663 & -.355 \\
ortalamaları & DJ & .166 & .200 & .202 & -1.348 \\
& KM & .115 & .200 & .536 & -.017 \\
\hline
\end{tabular}

Bu çalışmadaki kümeleme analizinde K-Means tekniği uygulanmıştır. Yapılan ikili, üçlü, dörtlü ve beşli atamalar sonucunda en çok üyenin ikili atamalarda olduğu belirlenmiştir. Bu atamalar arasında en çok sayıya ulaşılan şubeler tespit edilerek çalışmaya dâhil edilmiştir. Deney grupları ve kontrol grubunda bulunan toplam 83 öğrenci araştırmanın çalışma grubu olarak belirlenmiştir. Uygulanan kümeleme analizi sonucunda gruplarda yer alan öğrencilerin dağılımlarına Tablo 2'de yer verilmiştir.

Tablo 2. Araştırma Grupları Öğrencilerinin Cinsiyete Göre Dağılımı

\begin{tabular}{crcccc}
\hline \multirow{2}{*}{ Gruplar } & \multicolumn{2}{c}{ K1z } & \multicolumn{2}{c}{ Erkek } & \multicolumn{2}{c}{ Toplam } \\
\cline { 2 - 6 } & $\boldsymbol{n}$ & $\boldsymbol{\%}$ & $\boldsymbol{n}$ & $\boldsymbol{\%}$ & $\boldsymbol{n}$ \\
\hline DB & 8 & 38.10 & 13 & 61.90 & 21 \\
DÖ & 10 & 50.00 & 10 & 50.00 & 20 \\
DJ & 8 & 44.44 & 10 & 55.56 & 18 \\
KM & 10 & 41.67 & 14 & 58.33 & 24 \\
\hline
\end{tabular}

\section{Etik Bildirim}

Bu çalışma doktora tezinden üretilmiş olup 01.01.2020 tarihinden önce yapıldı ğından etik kurul kararı zorunluluğu yoktur.

\section{Veri Toplama Araçları}

Araştırma verilerini etmek için akademik başarı testi ve Türkçe dersine yönelik motivasyon ölçeği kullanılmıştır.

\section{Akademik Başarı Testi}

Araştırmanın amaçları doğrultusunda BİOK, ÖTBB, Jigsaw II teknikleri ve mevcut uygulanan yöntemin Türkçe Dersi (1-8. Sınıflar) Öğretim Programı 7. Sınıf Kazanımları üzerindeki etki düzeyinin belirlenmesi amacıyla araştırmacı tarafından 7. sınıf TÜDÖP'e yönelik akademik başarı testi geliştirilmiştir. Başarı testi hazırlanırken 7. sınıf düzeyine uygun olan ulaşılan bütün kaynaklar gözden geçirilmiştir. Bu doğrultuda; Talim Terbiye Kurulu tarafından kullanılması uygun bulunan 7. sınıf Türkçe ders ve çalışma kitapları, 7. sınıf Türkçe test kitapları, öğretmenler tarafından hazırlanmış test soruları, test kitapları, EBA'daki sorular, yaprak testler, ilgili alanda yapılmış yüksek lisans ve doktora tezleri, sınavlarda çıkan sorular (MEB'in yaptığı sınavlar) dikkatli bir şekilde incelenmiştir. Başarı testinde yer alan sorular hazırlanırken; öğrenci düzeyine uygun olmasına ve farklı soru tipleri kullanılmasına dikkat edilmiştir. Soruların öğrenci tarafından daha kolay kavranılmasını ve anlaşılmasını sağlamak için görseller kullanılmıştır. Bu doğrultuda taranan kaynaklardaki soru tiplerinde ne tür görsellerin tercih edildiği incelenmiş ve buna göre karar verilmiştir. Akademik başarı testi geliştirilirken her bir kazanım için en az beş soru olmak üzere dört seçenekten oluşan 41 soru hazırlanmıştır. Hazırlanan başarı testindeki sorular uzman görüşüne sunulmuştur. Araştırmacı uzmanların değerlendirmelerini dikkate alarak gerekli değişiklik ve düzeltmeleri yapmıştır. Geliştirilen akademik başarı testi Sivas il merkezinde yer alan beş farklı ortaokulda 296 sekizinci sınıf öğrencisine 
uygulanmıştır. Ön uygulama yapılan testler tek tek kontrol edilmiş ve içlerinden 17 tanesi eksik ve hatalı doldurulduğu için analize dâhil edilmemiştir. Geriye kalan 279 veri üzerinden jMetrik 4.0 programı kullanılarak başarı testinin geçerlik ve güvenirlik analizleri yapılmıştır.

Akademik başarı testinde yer alan 4 sorunun $(3,4,21$ ve 28. maddeler) madde ayırt edicilik değerlerinin 0.19 ve daha altında değer aldığı, 2 sorunun ( 5 ve 35 . maddeler) 0.20 ve 0.29 arasında değer aldığı saptanmıştır. Başarı testinde kalan sorular kapsam geçerliğini sağladığından bu soruların testten çıkarılması uygun görülmüştür. Geriye kalan soruların tekrar jMetrik 4.0 analizi yapıldığında testin ayırt edicilik indeksinin ve madde güçlük indeksinin uygun aralıkta yer aldığı belirlenmiştir. Teste ilişkin analizler bittiğinde toplamda 34 maddeden oluşan bir akademik başarı testi elde edilmiştir. Testin ortalama madde güçlük değeri 0.53 olarak tespit edilmiştir. Yapılan jMetrik 4.0 analizinde belirlenen KR-21 değerinin 0.91, Guttman's L2 değerinin 0.91 olduğu belirlenmiştir. Bu doğrultuda geliştirilen akademik başarı testinin yüksek güvenirliğe sahip olduğu yorumunda bulunulabilir.

\section{Türkçe Dersine Yönelik Motivasyon Ölçeği}

Öğrencilerin Türkçe dersine yönelik motivasyonlarını belirlemek amacıyla Arslan ve Taşgın (2019) tarafından geliştirilen "Türkçe Dersine Yönelik Motivasyon Ölçeği"nin kullanılması uygun görülmüştür. Ölçek "Motivasyonsuzluk" (17 madde), "İçsel Motivasyon" (11 madde), "Hedef Motivasyonu" (9 madde), "Dışsal Motivasyon" ( 8 madde) olmak üzere 4 boyuttan ve toplamda 45 maddeden oluşmaktadır. Ölçek; "Kesinlikle Katılmıyorum=1" ile "Kesinlikle Katılıyorum=5" arasında derecelemeye sahip beşli likert tipinde düzenlenmiştir. Ölçeğin Cronbach's Alpha güvenirlik kat sayısı motivasyonsuzluk alt boyutunda .97 , içsel motivasyon alt boyutunda .89 , hedef motivasyonu alt boyutunda .89 , dişsal motivasyon alt boyutunda .86 ve toplam maddelerde .95 olarak bulunmuştur. Ölçekten alınabilecek en yüksek puan 225, en düşük puan ise $45^{\prime}$ tir.

\section{Verilerin Toplanması ve Analizi}

Araştırmaya ilişkin gerekli izinler alındıktan sonra her iki okulla da görüşülerek yedinci sınıf öğrencilerinin araştırma için gerekli olan öğrenci bilgileri temin edilmiştir. Elde edilen bilgiler bilgisayar ortamına aktarılmış, bu bilgiler araştırma gruplarının heterojen bir şekilde denkleştirilmesi amacıyla kullanılmıştır. Araştırma gruplarının belirlenmesi için elde edilen bilgilere SPSS 25.0 programıla yapılan kümeleme analizi uygulanmıştır. Uygulama öğretmenlerinin haftalık ders planları incelenerek birlikte her bir grup için uygulama yapılacak güne ve saatine karar verilmiştir. TÜDÖP ve okulların öğretim planı incelenerek hangi ünitelerin hangi haftalarda işleneceği ve öğretmenlerin bu planları takip durumu, TÜDÖP'te yer alan kazanımlar belirlenmiştir. Uygulamanın yapılması için belirlenen haftalarda ders planında yer alan "Milli Kültürümüz" ve "Doğa ve Evren" üniteleri çalışma için belirlenmiştir. İki ünitenin toplam işlenme süresi sekiz hafta olup bu sürenin uygulamanın yapılması için uygun olduğu düşünülmüştür. Uygulama yapılacak ünitelerin dil bilgisi kazanımları göz önünde bulundurularak grupların haftalık çalışma planları oluşturulmuştur. DB, DÖ ve DJ gruplarında uygulama süreci sorumlu Türkçe öğretmenleri tarafından yürütülmüştür. Dersliklerde uygulama öğretmenleri dersi işlerken araştırmacı öğretmene hiçbir şekilde müdahale etmemiştir. Ancak araştırmacı uygulama öğretmenlerine uygulamanın nasıl yapılacağı konusunda gerekli tüm bilgileri uygulamadan önce vermiştir. Uygulama öğretmenleriyle yapılan görüşmeler neticesinde uygulama süreci sınıfların ders planları doğrultusunda her hafta iki saat olmak üzere sekiz hafta boyunca devam ettirilmiştir. Araştırma öncesinde başarı testi ve motivasyon ölçeği ön test olarak, araştırma sonunda son test olarak uygulanmıştır. Ayrıca çalışma bittikten dört hafta sonra başarı testi kalıcılık testi olarak tekrar uygulanmiştır. 
Araştırma kapsamında elde edilen veriler jMetrik 4.0 ve SPSS 25.0 paket programı kullanılarak analiz edilmiştir. Verilerin normallik değerini karşılayıp karşılamadığının tespit edilmesi amacıyla Kolmogorov-Smirnov testi ve Shapiro-Wilk testi uygulanmıştır. Yapılan analizlerde verilerin tamamının normallik varsayımını karşıladığı belirlenmiş ve parametrik analiz yöntemlerinin kullanılmasına karar verilmiştir. Bu doğrultuda TDYMÖ, akademik başarı testi analizinde bağımlı gruplar $\mathrm{t}$ testi ve tek yönlü ANOVA testleri kullanılmıştır.

\section{Bulgular}

$\mathrm{Bu}$ başlık altında araştırma sürecinde akademik başarı testi ve Türkçe dersine yönelik motivasyon ölçeğinden elde edilen bulgular yer almaktadır.

\section{Akademik Başarı Testine İlişkin Bulgular}

Tablo 3 'te araştırma gruplarının akademik başarı testinden aldıkları ön test puan ortalamalarına ilişkin tek yönlü ANOVA testine ait bulgular sunulmaktadır.

Tablo 3. Araştırma Gruplarının Türkçe Başarı Testinden Aldıkları Ön Test Puanlarına İlişkin Tek Yönlü ANOVA Testi Sonuçları

\begin{tabular}{llccclcccc}
\hline Ölçütler & Gruplar & $\boldsymbol{n}$ & $\overline{\mathbf{x}}$ & $\boldsymbol{s s}$ & $\begin{array}{l}\text { Varyans } \\
\text { kaynağı }\end{array}$ & sd & $\boldsymbol{F}$ & $\boldsymbol{p}$ & $\begin{array}{c}\text { Anlamlı fark } \\
\text { Tukey }\end{array}$ \\
\hline Türkçe & DB & 21 & 19.33 & 5.83 & Gruplar arası & 3 & & & \\
dersi & DÖ & 20 & 17.15 & 6.56 & Trar & 79 & 1.226 & .306 & Yok \\
başarı & DJ & 18 & 15.67 & 5.79 & Gruplar iç & 79 & & & \\
testi & KM & 24 & 16.88 & 6.37 & Toplam & 82 & & \\
\hline
\end{tabular}

Tablo 3'te bulunan araştırma gruplarının ön test puan ortalamaları incelendiğinde; araştırma gruplarının ön test sonuçları arasında gruplar arası anlamlı farklılık olmadığı ( $>$ >.05) belirlenmiştir. Bu doğrultuda araştırma gruplarının ön test puan ortalamaları açısından benzerlik gösterdiği ve araştırmanın kriterleri arasında yer alan yansızlık ilkesine riayet edildiği yorumunda bulunulabilir.

Araştırma gruplarının akademik başarı testinden aldıkları ön test ve son test puanlarının karşılaştırılmasına ilişkin bağımlı gruplar t testi sonuçları Tablo 4 'te yer almaktadır.

Tablo 4. Araştırma Gruplarının Ön Test-Son Test Puanlarına İlişkin Bağımlı Gruplar T Testi Sonuçları

\begin{tabular}{|c|c|c|c|c|c|c|c|}
\hline Gruplar & & $n$ & $\bar{x}$ & ss & $s d$ & $t$ & $p$ \\
\hline \multirow{2}{*}{ DB } & Ön test & 21 & 19.33 & 5.83 & \multirow{2}{*}{20} & \multirow{2}{*}{-3.717} & \multirow{2}{*}{$.001^{*}$} \\
\hline & Son test & 21 & 23.90 & 5.39 & & & \\
\hline \multirow{2}{*}{ DÖ } & Ön test & 20 & 17.15 & 6.56 & \multirow{2}{*}{19} & \multirow{2}{*}{-4.177} & \multirow{2}{*}{$.001^{*}$} \\
\hline & Son test & 20 & 23.75 & 6.91 & & & \\
\hline \multirow{2}{*}{ DJ } & Ön test & 18 & 15.67 & 5.79 & \multirow{2}{*}{17} & \multirow{2}{*}{-12.160} & \multirow{2}{*}{$.000^{*}$} \\
\hline & Son test & 18 & 22.94 & 6.26 & & & \\
\hline \multirow{2}{*}{ KM } & Ön test & 24 & 16.88 & 6.37 & \multirow{2}{*}{23} & \multirow{2}{*}{-.829} & \multirow{2}{*}{.416} \\
\hline & Son test & 24 & 17.50 & 5.95 & & & \\
\hline
\end{tabular}

${ }^{*} p<.05$

Tablo 4'teki bulgular incelendiğinde araştırma gruplarının akademik başarı ön test-son test verilerinin bağımlı gruplar $\mathrm{t}$ testi kullanılarak karşılaştırıldığı görülmektedir. Elde edilen sonuçlara göre; DB, DÖ ve DJ gruplarının ön test son test karşılaştırılmasında son test lehine olmak üzere anlamlı düzeyde farklılık olduğu $(\mathrm{p}<.5)$ saptanmıştır. KM grubunun ön test-son test karşılaştırmasında ise son test lehine olmak üzere bir miktar artış olmakla birlikte bu farklılığın anlamlı düzeyde olmadığı belirlenmiştir. 
Tablo 5'te araştırma gruplarının başarı testinden aldıkları son test puan ortalamalarına ilişkin tek yönlü ANOVA testine ait bulgular sunulmaktadır.

Tablo 5. Araştırma Gruplarının Türkçe Başarı Testinden Aldıkları Son Test Puanlarına Tek Yönlü ANOVA Testi Sonuçları

\begin{tabular}{llccclcccc}
\hline Ölçütler & Gruplar & $n$ & $\overline{\mathbf{x}}$ & ss & $\begin{array}{l}\text { Varyans } \\
\text { kaynağı }\end{array}$ & sd & $\boldsymbol{F}$ & $\boldsymbol{p}$ & $\begin{array}{c}\text { Anlamlı fark } \\
\text { Tukey }\end{array}$ \\
\hline Türkçe & DB & 21 & 23.90 & 5.39 & Gruplar arası & 3 & & & \\
dersi & DÖ & 20 & 23.75 & 6.91 & KM ile DB, DÖ, \\
başarı testi & DJ & 18 & 22.94 & 6.26 & Gruplar içi & 79 & 5.642 & $.001^{*}$ & $\begin{array}{c}\text { DJ arasında } \\
\end{array}$ \\
& KM & 24 & 17.50 & 5.95 & Toplam & 82 & & & \\
\hline
\end{tabular}

$* \bar{p} p .05$

Tablo 5'te yer alan veriler incelendiğinde; araştırma gruplarının akademik başarı puanları arasında anlamlı farklılık olduğu belirlenmiştir. Anlamlı farklılığın hangi gruplar arasında olduğunun tespiti amacıyla yapılan Tukey analizinden elde edilen bulgulara göre "KM ile DB, DÖ, DJ" grupları arasında DB, DÖ ve DJ grupları lehine olmak üzere anlamlı farklılığın olduğu ancak deney gruplarına uygulanan teknikler arasında bir farkın olmadığı görülmektedir.

Araştırma gruplarının başarı testinden aldıkları son test ve kalıcılık testi puanlarının karşılaştırılmasına ilişkin bağımlı gruplar t testi sonuçları Tablo 6' da yer almaktadır.

Tablo 6. Araştırma Gruplarının Son Test-Kalıcılık Testi Puanlarına İlişkin Bağımlı Gruplar T Testi

\begin{tabular}{|c|c|c|c|c|c|c|c|}
\hline \multicolumn{8}{|c|}{ Sonuçları } \\
\hline Gruplar & & $n$ & $\bar{x}$ & ss & $s d$ & $t$ & $p$ \\
\hline \multirow{2}{*}{ DB } & Son test & 21 & 23.90 & 5.39 & \multirow{2}{*}{20} & \multirow{2}{*}{1.858} & \multirow{2}{*}{.078} \\
\hline & Kalıcılık testi & 21 & 22.14 & 6.39 & & & \\
\hline \multirow{2}{*}{ DÖ } & Son test & 20 & 23.75 & 6.91 & \multirow{2}{*}{19} & \multirow{2}{*}{-457} & \multirow{2}{*}{.653} \\
\hline & Kalıcılık testi & 20 & 24.10 & 5.67 & & & \\
\hline \multirow{2}{*}{ DJ } & Son test & 18 & 22.94 & 6.26 & \multirow{2}{*}{17} & \multirow{2}{*}{-.658} & \multirow{2}{*}{.520} \\
\hline & Kalıcılık testi & 18 & 23.50 & 5.29 & & & \\
\hline \multirow{2}{*}{ KM } & Son test & 24 & 17.50 & 5.95 & \multirow{2}{*}{23} & \multirow{2}{*}{.332} & \multirow{2}{*}{.743} \\
\hline & Kalıcılık testi & 24 & 17.25 & 6.90 & & & \\
\hline
\end{tabular}

Tablo 6'daki bulgular incelendiğinde araştırma gruplarının akademik başarı son test-kalıcllık testi puan ortalamalarının bağımlı gruplar t testi kullanılarak karşılaştırıldığı görülmektedir. İşbirlikli öğrenme tekniklerinin uygulandığı DB, DÖ, DJ ve mevcut yöntemin uygulandığı KM grubunda yer alan öğrencilerin akademik başarı puanları son test-kalıcılık testi puanları arasında anlamlı düzeyde farklılık olmadığı (p>.05) görülmektedir. Öğrencilerin öğrenme süreci içinde öğrendiklerini unutmadıkları yorumunda bulunulabilir. Bu açıdan DB, DÖ, DJ ve KM grupları arasında anlamlı düzeyde farklılık olmadığı ve kalıcılık üzerinde hem işbirlikli öğretim tekniklerinin hem de mevcut öğrenme yönteminin etkisinin birbirine yakın olduğu yorumunda bulunulabilir.

Tablo 7'de araştırma gruplarının başarı testinden aldıkları kalıcılık testi puan ortalamalarına ilişkin tek yönlü ANOVA testine ait bulgular sunulmaktadır. 
Tablo 7. Araştırma Gruplarının Başarı Testinden Aldıkları Kalıcılık Testi Puanlarına Tek Yönlü ANOVA Testi Sonuçları

\begin{tabular}{llccclcccc}
\hline Ölçütler & Gruplar & $n$ & $\overline{\mathbf{x}}$ & ss & $\begin{array}{l}\text { Varyans } \\
\text { kaynağı }\end{array}$ & sd & $\boldsymbol{F}$ & $\boldsymbol{p}$ & $\begin{array}{c}\text { Anlamlı fark } \\
\text { Tukey }\end{array}$ \\
\hline Türkçe & DB & 21 & 22.14 & 5.39 & Gruplar & 3 & & & \\
dersi & DÖ & 20 & 24.10 & 6.91 & arası & & 5.601 & $.001^{*}$ & KM ile DB, DÖ, \\
başarı & DJ & 18 & 23.50 & 6.26 & Gruplar içi & 79 & & & DJ arasında \\
testi & KM & 24 & 17.25 & 5.95 & Toplam & 82 & & & \\
$* p<.05$ & & & & & & & & &
\end{tabular}

Tablo 7'de yer alan araştırma gruplarına ilişkin kalıcllık testi puan ortalamaları ve ANOVA testi ile yapılan gruplar arası karşılaştırmalar incelendiğinde; grupların kalıcılık testinde aldıkları puan ortalamaları anlamlı farklılık olduğu sonucuna (p.<05) ulaşılmıştır. Anlamlı farklılığın hangi gruplar arasında olduğunun tespiti amacıyla yapılan Tukey analizinden elde edilen bulgulara göre "KM ile DB, DÖ, DJ" grupları arasında DB, DÖ ve DJ grupları lehine olmak üzere anlamlı farklılığın olduğu görülmektedir.

Türkçe Dersine Yönelik Öğrenme Motivasyonuna İlişkin Bulgular

Tablo 8'de araştırma gruplarının TDYMÖ'den aldıkları ön test puan ortalamalarına ilişkin tek yönlü ANOVA testine ait bulgulara yer verilmektedir.

Tablo 8. Araştırma Gruplarının TDYMÖ’den Aldıkları Ön Test Puanlarına İlişkin Tek Yönlü ANOVA

\begin{tabular}{|c|c|c|c|c|c|c|c|c|c|}
\hline \multicolumn{10}{|c|}{ Testi Sonuçları } \\
\hline Ölçütler & Gruplar & $n$ & $\overline{\mathbf{x}}$ & ss & $\begin{array}{l}\text { Varyans } \\
\text { kaynağ1 }\end{array}$ & $s d$ & $F$ & $p$ & $\begin{array}{c}\text { Anlamlı } \\
\text { fark }\end{array}$ \\
\hline \multirow{4}{*}{ 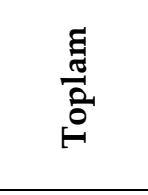 } & DB & 21 & 174.62 & 16.88 & Crunlar aract & 3 & \multirow{4}{*}{1.166} & \multirow{4}{*}{.328} & \multirow{4}{*}{ Yok } \\
\hline & DÖ & 20 & 184.20 & 12.91 & Gruplar arasi & 3 & & & \\
\hline & DJ & 18 & 178.56 & 8.98 & Gruplar içi & 79 & & & \\
\hline & KM & 24 & 183.04 & 27.38 & Toplam & 82 & & & \\
\hline \multirow{4}{*}{ 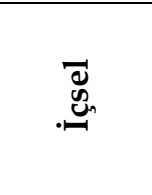 } & DB & 21 & 38.05 & 5.88 & & & \multirow{4}{*}{.568} & \multirow{4}{*}{.637} & \multirow{4}{*}{ Yok } \\
\hline & DÖ & 20 & 40.00 & 4.84 & Gruplar arasi & 3 & & & \\
\hline & DJ & 18 & 40.11 & 5.25 & Gruplar içi & 79 & & & \\
\hline & KM & 24 & 39.54 & 6.43 & Toplam & 82 & & & \\
\hline \multirow{4}{*}{ 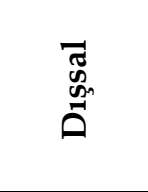 } & DB & 21 & 32.62 & 5.59 & & & \multirow{4}{*}{2.315} & \multirow{4}{*}{.082} & \multirow{4}{*}{ Yok } \\
\hline & DÖ & 20 & 35.85 & 3.42 & Gruplar arası & 3 & & & \\
\hline & DJ & 18 & 35.72 & 3.39 & Gruplar içi & 79 & & & \\
\hline & KM & 24 & 33.63 & 5.57 & Toplam & 82 & & & \\
\hline \multirow{4}{*}{ 㫕 } & DB & 21 & 33.29 & 5.36 & & & \multirow{4}{*}{.993} & \multirow{4}{*}{.401} & \multirow{4}{*}{ Yok } \\
\hline & DÖ & 20 & 35.05 & 7.00 & Gruplar arası & 3 & & & \\
\hline & DJ & 18 & 33.78 & 3.26 & Gruplar içi & 79 & & & \\
\hline & KM & 24 & 35.96 & 6.19 & Toplam & 82 & & & \\
\hline \multirow{4}{*}{ 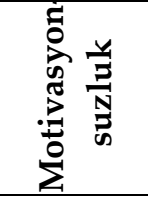 } & DB & 21 & 71.81 & 10.73 & Cuunlar anoc & 2 & \multirow{4}{*}{.617} & \multirow{4}{*}{.606} & \multirow{4}{*}{ Yok } \\
\hline & DÖ & 20 & 74.80 & 1.74 & Gruparar arasi & 3 & & & \\
\hline & DJ & 18 & 70.56 & 4.16 & Gruplar içi & 79 & & & \\
\hline & KM & 24 & 71.92 & 15.31 & Toplam & 82 & & & \\
\hline
\end{tabular}

Tablo 8'de bulunan araştırma gruplarının TDYMÖ'den aldıkları ön test puan ortalamaları analiz edildiğinde; tek yönlü ANOVA testi sonuçlarında gruplar arası anlamlı farklılı̆̆ın p>.05 bulunmadığı tespit edilmiştir. Buna göre uygulama öncesinde araştırma gruplarında yer alan öğrencilerin motivasyon düzeylerinin birbirine benzer olduğu yorumunda bulunulabilir. Araştırma 
gruplarının Türkçe dersine yönelik motivasyon düzeyleri açısından da yansızlık kriterleri karşılanmaktadır.

DB grubu öğrencilerinin TDYMÖ'den aldıkları ön test ve son test puanlarının ölçeğin toplamında ve tüm faktörlerinde karşılaştırılmasına ilişkin bağımlı gruplar $t$ testi sonuçları Tablo 9'da yer almaktadir.

Tablo 9. DB Grubunun TDYMÖ Ön Test-Son Test Puanlarına İlişkin Bağımlı Gruplar T Testi Sonuçları

\begin{tabular}{|c|c|c|c|c|c|c|c|}
\hline Ölçek & & $n$ & $\overline{\mathbf{x}}$ & ss & $s d$ & $t$ & $p$ \\
\hline \multirow{2}{*}{ Toplam } & Ön test & 21 & 174.62 & 16.88 & \multirow{2}{*}{20} & \multirow{2}{*}{-1.324} & \multirow{2}{*}{.201} \\
\hline & Son test & 21 & 183.06 & 27.57 & & & \\
\hline \multirow{2}{*}{ İçsel } & Ön test & 21 & 38.05 & 5.88 & \multirow{2}{*}{20} & \multirow{2}{*}{-2.687} & \multirow{2}{*}{$.014^{*}$} \\
\hline & Son test & 21 & 42.95 & 8.74 & & & \\
\hline \multirow{2}{*}{ Dişsal } & Ön test & 21 & 32.62 & 5.59 & \multirow{2}{*}{20} & \multirow{2}{*}{-1.031} & \multirow{2}{*}{.315} \\
\hline & Son test & 21 & 33.86 & 6.18 & & & \\
\hline \multirow{2}{*}{ Hedef } & Ön test & 21 & 33.29 & 5.36 & \multirow{2}{*}{20} & \multirow{2}{*}{-2.129} & \multirow{2}{*}{$.046^{*}$} \\
\hline & Son test & 21 & 36.14 & 6.78 & & & \\
\hline \multirow{2}{*}{$\begin{array}{l}\text { Motivasyon- } \\
\text { suzluk }\end{array}$} & Ön test & 21 & 71.81 & 10.73 & \multirow{2}{*}{20} & \multirow{2}{*}{.066} & \multirow{2}{*}{.948} \\
\hline & Son test & 21 & 71.57 & 13.20 & & & \\
\hline
\end{tabular}
$* p<.05$

Tablo 9'da bulunan bulgulara bakıldığında; DB grubunda yer alan öğrencilerin TDYMÖ'den aldıkları ön test ve son test puanları arasında içsel motivasyon faktörü açısından son test lehine olmak üzere anlamlı farklılı̆̆ın olduğu ( $<<.05)$, toplam puan ve diğer faktörler açısından ise anlamlı farklılığın (p>.05) bulunmadığı tespit edilmiştir. Bu doğrultuda BİOK tekniğinin öğrencilerin motivasyonları üzerinde olumlu etki yaptığı, içsel motivasyon ve hedef motivasyonu faktörlerinde anlamlı düzeyde farklılık oluşturduğu; TDYMÖ'nün toplam puanı ve diğer faktörlerinde son test lehine olmak üzere puan artışlarının olduğu ancak artışların istatistiksel düzeyde anlamlı farklılık oluşturacak düzeyde olmadığı görülmektedir.

DÖ grubu öğrencilerinin TDYMÖ'den aldıkları ön test ve son test puanlarının ölçeğin toplamı ve tüm faktörlerinde karşılaştırılmasına ilişkin bağımlı gruplar $t$ testi sonuçları Tablo 10'da sunulmaktadır.

Tablo 10. DÖ Grubunun TDYMÖ Ön Test-Son Test Puanlarına İlişkin Bağımlı Gruplar T Testi

\begin{tabular}{|c|c|c|c|c|c|c|c|}
\hline \multicolumn{8}{|c|}{ Sonuçları } \\
\hline Ölçek & & $n$ & $\overline{\mathbf{x}}$ & ss & $s d$ & $t$ & $p$ \\
\hline \multirow{2}{*}{ Toplam } & Ön test & 20 & 184.20 & 12.91 & \multirow{2}{*}{19} & \multirow{2}{*}{-6.556} & \multirow{2}{*}{$.000^{*}$} \\
\hline & Son test & 20 & 206.95 & 9.89 & & & \\
\hline \multirow{2}{*}{ İçsel } & Ön test & 20 & 40.00 & 4.84 & \multirow{2}{*}{19} & \multirow{2}{*}{-7.028} & \multirow{2}{*}{$.000^{*}$} \\
\hline & Son test & 20 & 50.30 & 4.34 & & & \\
\hline \multirow{2}{*}{ Dişsal } & Ön test & 20 & 35.85 & 3.42 & \multirow{2}{*}{19} & \multirow{2}{*}{-2.577} & \multirow{2}{*}{$.018^{*}$} \\
\hline & Son test & 20 & 38.10 & 2.61 & & & \\
\hline \multirow{2}{*}{ Hedef } & Ön test & 20 & 35.05 & 7.00 & \multirow{2}{*}{19} & \multirow{2}{*}{-2.399} & \multirow{2}{*}{$.027^{*}$} \\
\hline & Son test & 20 & 39.55 & 4.32 & & & \\
\hline \multirow{2}{*}{ Motivasyonsuzluk } & Ön test & 20 & 74.80 & 1.74 & \multirow{2}{*}{19} & \multirow{2}{*}{-5.059} & \multirow{2}{*}{$.000^{*}$} \\
\hline & Son test & 20 & 78.70 & 3.11 & & & \\
\hline
\end{tabular}
$* \overline{p<.05}$

Yukarıda yer alan Tablo 10'daki bulgular analiz edildiğinde; DÖ grubunda yer alan öğrencilerin TDYMÖ'den aldıkları ön test ve son test puanları arasında toplam puan ve tüm faktörler açısından anlamlı farklılığın $\mathrm{p}<.05$ oluştuğu tespit edilmiştir. Bu farklılığın toplam puan ve tüm 
faktörlerde son test lehine olduğu görülmektedir. Elde edilen bu sonuçlar değerlendirildiğinde; ÖTBB tekniğinin öğrencilerin Türkçe dersine yönelik motivasyon puanları üzerinde olumlu etki oluşturduğu sonucuna ulaşılmaktadır. ÖTBB tekniği öğrencilerin Türkçe dersine yönelik ilgilerini artırarak onların isteklilikleri üzerinde bir fark yarattığı yorumunda bulunulabilir.

DJ grubu öğrencilerinin TDYMÖ’den aldıkları ön test ve son test puanlarının ölçeğin toplamı ve tüm faktörlerinde karşılaştırılmasına ilişkin bağımlı gruplar $t$ testi sonuçları Tablo $11^{\prime}$ de sunulmaktadir.

Tablo 11. DJ Grubunun TDYMÖ Ön Test-Son Test Puanlarına İlişkin Bağımlı Gruplar T Testi

\begin{tabular}{|c|c|c|c|c|c|c|c|}
\hline \multicolumn{8}{|c|}{ Sonuçları } \\
\hline Ölçek & & $n$ & $\overline{\mathbf{x}}$ & ss & $s d$ & $t$ & $p$ \\
\hline \multirow{2}{*}{ Toplam } & Ön test & 18 & 178.55 & 8.98 & \multirow{2}{*}{17} & \multirow{2}{*}{-4.028} & \multirow{2}{*}{$.001^{*}$} \\
\hline & Son test & 18 & 194.89 & 14.50 & & & \\
\hline \multirow{2}{*}{ İçsel } & Ön test & 18 & 40.11 & 5.25 & \multirow{2}{*}{17} & \multirow{2}{*}{-2.329} & \multirow{2}{*}{$.032^{*}$} \\
\hline & Son test & 18 & 43.83 & 4.50 & & & \\
\hline \multirow{2}{*}{ Dişsal } & Ön test & 18 & 35.72 & 3.39 & \multirow{2}{*}{17} & \multirow{2}{*}{-.268} & \multirow{2}{*}{.792} \\
\hline & Son test & 18 & 36.06 & 3.64 & & & \\
\hline \multirow{2}{*}{ Hedef } & Ön test & 18 & 33.78 & 3.26 & \multirow{2}{*}{17} & \multirow{2}{*}{-3.416} & \multirow{2}{*}{$.003^{*}$} \\
\hline & Son test & 18 & 36.78 & 3.77 & & & \\
\hline \multirow{2}{*}{$\begin{array}{l}\text { Motivasyon- } \\
\text { suzluk }\end{array}$} & Ön test & 18 & 70.56 & 4.16 & \multirow{2}{*}{17} & \multirow{2}{*}{-4.051} & \multirow{2}{*}{$.001^{*}$} \\
\hline & Son test & 18 & 78.22 & 8.57 & & & \\
\hline
\end{tabular}
$* p<.05$

Tablo 11'deki sonuçlar incelendiğinde; DJ grubunda yer alan öğrencilerin TDYMÖ’den aldıkları ön test ve son test puanları arasında toplam puan, içsel motivasyon, hedef motivasyonu ve motivasyonsuzluk faktörleri açısından anlamlı farklılığın ( $\mathrm{p}<.05)$ oluştuğu; dışsal faktörde ise anlamlı farklılığın oluşmadığı (p>.05) tespit edilmiştir. Bu farklılığın toplam puan ve faktörlerde son test lehine olduğu görülmektedir. Elde edilen bu sonuçlar değerlendirildiğinde Jigsaw II tekniğinin öğrencilerin Türkçe dersine yönelik motivasyon puanları üzerinde olumlu etki oluşturduğu sonucuna ulaşılmaktadır. Jigsaw II tekniği öğrencilerin Türkçe dersine yönelik ilgilerini artırarak onların isteklilikleri üzerinde bir fark yarattı̆̆ı yorumunda bulunulabilir.

KM grubu öğrencilerinin TDYMÖ'den aldıkları ön test ve son test puanlarının ölçeğin toplamı ve tüm faktörlerinde karşılaştırılmasına ilişkin bağımlı gruplar $t$ testi sonuçları Tablo 12'de sunulmaktadır.

Tablo 12. KM Grubunun TDYMÖ Ön Test-Son Test Puanlarına İlişkin Bağımlı Gruplar T Testi

\begin{tabular}{|c|c|c|c|c|c|c|c|}
\hline \multicolumn{8}{|c|}{ Sonuçları } \\
\hline Ölçek & & $n$ & $\overline{\mathbf{x}}$ & ss & $s d$ & $t$ & $p$ \\
\hline \multirow{2}{*}{ Toplam } & Ön test & 24 & 183.04 & 27.38 & \multirow{2}{*}{23} & \multirow{2}{*}{1.904} & \multirow{2}{*}{.070} \\
\hline & Son test & 24 & 174.63 & 33.40 & & & \\
\hline \multirow{2}{*}{ İçsel } & Ön test & 24 & 39.54 & 6.43 & \multirow{2}{*}{23} & \multirow{2}{*}{.605} & \multirow{2}{*}{.551} \\
\hline & Son test & 24 & 38.25 & 11.23 & & & \\
\hline \multirow{2}{*}{ Dişsal } & Ön test & 24 & 33.63 & 5.57 & \multirow{2}{*}{23} & \multirow{2}{*}{1.071} & \multirow{2}{*}{.295} \\
\hline & Son test & 24 & 31.75 & 7.63 & & & \\
\hline \multirow{2}{*}{ Hedef } & Ön test & 24 & 35.96 & 6.19 & \multirow{2}{*}{23} & \multirow{2}{*}{1.439} & \multirow{2}{*}{.164} \\
\hline & Son test & 24 & 33.54 & 9.61 & & & \\
\hline \multirow{2}{*}{$\begin{array}{l}\text { Motivasyon- } \\
\text { suzluk }\end{array}$} & Ön test & 24 & 71.92 & 15.31 & \multirow{2}{*}{23} & \multirow{2}{*}{.241} & \multirow{2}{*}{.812} \\
\hline & Son test & 24 & 71.08 & 17.42 & & & \\
\hline
\end{tabular}


Tablo 12' de yer alan sonuçlara göre; KM grubu öğrencilerinin TDYMÖ'den aldıkları ön test ve son test puanları arasında toplam puan, içsel motivasyon, hedef motivasyonu ve motivasyonsuzluk faktörleri açısından anlamlı farklılığın ( $p>.05)$ olmadığı tespit edilmiştir. Elde edilen bu sonuçlar değerlendirildiğinde mevcut uygulanan yöntemin öğrencilerin Türkçe dersine yönelik motivasyon puanları üzerinde herhangi bir etki oluşturmadığı şeklinde yorumlanabilir.

\section{Tartışma, Sonuç ve Öneriler}

Araştırma gruplarının ön test puan ortalamaları incelendiğinde; araştırma gruplarının ön test sonuçları arasında gruplar arası anlamlı farklılık olmadığı belirlenmiştir. Bu doğrultuda araştırma gruplarının ön test puan ortalamaları açısından benzerlik gösterdiği ve araştırmanın kriterleri arasında yer alan yansızlık ilkesine riayet edildiği yorumunda bulunulabilir. Elde edilen sonuçlara göre; ön testson test karşılaştırılmasında işbirlikli öğrenme tekniklerinin uygulandığg gruplarda son test lehine olmak üzere anlamlı düzeyde farklılık olduğu; mevcut öğrenme yönteminin uygulandığı grupta ise son test lehine olmak üzere bir miktar artış olmakla birlikte bu farklılığın anlamlı düzeyde olmadığı belirlenmiştir.

Araştırma gruplarının son test puanlarına göre; akademik başarı puanları arasında anlamlı farklılık olduğu saptanmıştır. Bu farklılığın işbirlikli öğrenme teknikleri uygulanan gruplar ile mevcut öğrenme yönteminin uygulandığı grup arasında işbirlikli öğrenme tekniklerinin uygulandığı gruplar lehine olduğu görülmüştür. Bu doğrultuda araştırmada uygulanan BİOK, ÖTBB ve Jigsaw II tekniklerinin öğrencilerin akademik başarılarını artırmada benzer etkiye sahip olduğu ve mevcut öğrenme yöntemine göre öğrencilerin akademik başarıları ve öğrendiklerinin kalıcılı̆̆ı üzerinde daha etkili oldukları yorumunda bulunulabilir. Araştırma gruplarının akademik başarı son test-kalıcılık testi puan ortalamalarında; araştırma grupları arasında anlamlı düzeyde farklılık olmadığı görülmektedir. Öğrencilerin öğrenme süreci içinde öğrendiklerini unutmadıkları yorumunda bulunulabilir. Bu açıdan araştırma gruplarında kullanılan öğrenme tekniklerinin öğrenme kalıcılığı etkisinin birbirine yakın olduğu yorumunda bulunulabilir. Ancak araştırma gruplarına ilişkin kalıcılık testi puan ortalamaları incelendiğinde; grupların kalıcılık testinde aldıkları puan ortalamalarında işbirlikli öğrenme teknikleri lehine olmak üzere anlamlı farklılık olduğu sonucuna ulaşılmıştır. Genel olarak değerlendirildiğinde; işbirlikli öğrenme tekniklerinin öğrencilerin akademik başarılarını artırmada ve kalıcılığını sağlamada mevcut öğrenme yöntemine kıyasla daha etkili olduğu belirlenmiştir. Alanyazında bu bulguları destekleyen birçok çalışmanın bulunduğu belirlenmiştir.

Alanyazında yapılan çalışmalar incelendiğinde; BïOK tekniğinin mevcut öğrenme yöntemine göre öğrencilerin akademik başarılarını daha olumlu etkilediği bulgusuna ulaşılan çalışmalar olduğu görülmektedir (Genlott ve Grönlund, 2013; Gonzales ve Torres, 2015; Karafkan ve Aghazadeh, 2015; Masnaini, Copriady ve Osman, 2018; Yaman, 1999; Zarei, 2012). BİOK tekniğinin öğrencilerin akademik başarılarının mevcut öğrenme yöntemiyle kıyaslandığı bu çalışmaların yanı sıra kontrol grubu olmayan sadece deney grubunun yer aldığı çalışmalarda da BİOK tekniğinin etkili olduğu bulgusuna ulaşılmıştır (Khuzaemah ve Herawati, 2017). Yapılan bu araştırmada BİK tekniğiyle ilgili elde edilen bir diğer bulgu da son test ile uygulamadan dört hafta sonra yapılan kalıcllık testi arasında anlamlı farklılık olmadığıdır. Uygulama süresince işlenen konular bittiği için aynı konular tekrar işlenmemiştir. Dolayısıyla da öğrencilerin puanlarını artıracak herhangi bir öğrenme gerçekleşmemiştir. Öğrencilerin puanlarında belirgin bir düşmenin olmaması öğrencilerin öğrendiklerinin kalıcı olmasında BİOK tekniğinin etkili olduğu şeklinde yorumlanabilir. Bu çalışmadan kalıcılık ile ilgili olarak elde edilen bulgular Yurdabakan ve Cihanoğlu (2009) tarafından yapılan çalışmayla benzerlik göstermektedir. 
Alanyazında farklı bulgular da yer almaktadır. Bozpolat'ın (2012) yaptığı araştırma sonuçlarında bu çalışmanın aksine BİOK lehine öğrencilerin kalıcılık puanları arasında anlamlı farklılık olduğu ve öğrencilerin puanlarının kalıcılık testi lehine artış gösterdiği belirlenmiştir.

BİOK tekniğinin diğer işbirlikli tekniklerle etki düzeyinin karşılaştırıldığı çalışmalara bakıldığında farklı sonuçların olduğu görülmektedir. Karafkan ve Aghazadeh (2015) tarafından yapılan çalışmada BİOK, GA teknikleri ve mevcut öğrenme yönteminin akademik başarı üzerindeki etki düzeyi karşılaştırılmış ve bu çalışmayla uyumlu olarak işbirlikli öğretim teknikleri arasında anlamlı farklılık bulunmamıştır. Ancak işbirlikli öğretim teknikleri ile mevcut öğrenme yöntemi arasında işbirlikli öğretim teknikleri lehine olmak üzere anlamlı farklılık olduğu saptanmıştır. Bu çalışmada işbirlikli öğretim tekniklerinin uygulandığı deney grupları arasında anlamlı farklılık bulunmamasına karşın Zarei'nin (2012) yaptığı araştırmada BİOK, ÖTBB teknikleri ve mevcut öğrenme yöntemi karşılaştırılmış ve BİOK tekniğinin diğerlerine göre öğrencilerin akademik başarılarını daha olumlu etkilediği sonucuna ulaşılmıştır. BİOK tekniğinin öğrenci başarıları üzerinde sadece mevcut öğrenme yöntemine göre değil ÖTBB tekniğine göre de daha olumlu etkiye sahip olduğu saptanmıştır.

ÖTBB ile ilgili alanyazında yapılan araştırmalarda bu çalışma ile uyumlu olarak ÖTBB tekniğinin öğrencilerin akademik başarılarını mevcut öğrenme yöntemine göre daha olumlu etkilediğinin tespit edildiği çalışmaların olduğu görülmüştür (Akar ve Doymuş, 2015; Jalilifar, 2010; Kartal ve Özbek, 2016; Ocak ve Küçükilhan, 2014). ÖTBB tekniğinin tek gruplu deneysel desen olarak kullanıldığı araştırmaların sonuçlarına bakıldığında; Tiantong ve Teemuangsai (2013), Ahmad (2015), Kim (2018) tarafından yapılan araştırmalarda ÖTBB tekniğinin öğrencilerin akademik başarılarını artırdığı belirlenmiştir. Bu çalışmada ÖTBB tekniği ile BİOK ve Jigsaw II teknikleri arasında öğrencilerin akademik başarıları arasında anlamlı farklılık bulunmamıştır. Alanyazında ÖTBB tekniği ile farklı işbirlikli öğretim tekniklerinin karşılaştırıldığı çalışmalar yer almaktadır. Bu çalışma ile uyumlu olarak Çalıklar'ın (2015) yaptığı araştırmada ÖTBB ve TOT teknikleri karşılaştırılmış, öğrencilerin akademik başarıları üzerinde iki teknik arasında anlamlı farklılık bulunamamıştır. İlgaz ve Çelen (2017) tarafından yapılan çalışmada Jigsaw ve ÖTBB tekniklerinin karşılaştırmalı olarak öğrencilerin akademik başarıları üzerindeki etkisi araştıılmış ve birbirleri arasında anlamlı farklılık olmadığı belirlenmiştir. Jalilifar (2010) tarafından yapılan araştırmada ÖTBB ile GA tekniklerini karşılaştııılmış ÖTBB tekniğinin GA tekniğine göre öğrencilerin akademik başarılarını artırmada daha etkili olduğu sonucuna ulaşılmıştır. Baydar'ın (2015) yaptığı çalışmada ÖTBB ile Jigsaw teknikleri karşılaştırılmış ve ÖTBB tekniğinin Jigsaw tekniğine göre daha etkili olduğu tespit edilmiştir. Öğrencilerin akademik başarıları üzerinde Gambari, Yusuf ve Thomas'ın (2015) ÖTBB ve BÖ tekniklerinin karşılaştırılmasında ÖTBB; Gambari ve Yusuf'un (2017) ÖTBB, Jigsaw II ve TDB tekniklerini karşılaştırmasında Jigsaw II; Fika'nın (2020) ÖTBB ve Jigsaw tekniklerini karşılaştırmasında Jigsaw tekniğinin daha etkili olduğu bulgusuna ulaşılmıştır.

Alanyazında yapılan çalışmalar incelendiğinde; Jigsaw II tekniğinin mevcut öğrenme yöntemine göre öğrencilerin akademik başarılarını daha olumlu etkilediği bulgusuna ulaşılan çalışmalar olduğu görülmektedir (Avcı ve Fer, 2004; Evcim ve İpek, 2013; Nurwanti vd., 2019; Putri, 2013; Yılar, 2016). Tek gruplu Jigsaw II tekniği ile yapılan çalışmalarda ise Jigsaw II tekniğinin öğrencilerin akademik başarılarını olumlu etkilediği belirlenmiştir. (Tabiolo ve Rogayan, 2019). Diğer Jigsaw teknikleri ile yapılan çalışmalara bakıldığında da öğrencilerin akademik başarılarını artırmada mevcut öğrenme yöntemine göre etkili oldukları görülmektedir (Juliana ve Surya, 2017). Ayrıca Jigsaw tekniği ile diğer işbirlikli tekniklerin karşılaştırıldığı çalışmaların olduğu saptanmıştır. Yılar, Şimşek, Topkaya ve Balkaya (2015) tarafından yapılan araştırmada Jigsaw tekniği ile OYU tekniği karşılaştırılmış ve öğrencilerin akademik başarıları üzerinde bu çalışmayla uyumlu olarak aralarında 
anlamlı farklılık olmadığı belirlenmiştir. Ancak Jigsaw II ve diğer teknikler kullanılarak yapılan çalışmalarda işbirlikli teknikler arasında farklılıkların olduğu da görülmektedir. Koç, Yıldız, Çalıklar ve Şimşek' in (2016) yaptığı çalışma bulguları incelendiğinde Jigsaw II ve OYS tekniklerinin karşılaştırıldığı ve öğrencilerin başarıları üzerinde Jigsaw II tekniğinin daha etkili olduğu görülmektedir. Berlyana ve Purwaningsih (2019) tarafından yapılan çalışmada Jigsaw ile ÖTBB teknikleri karşılaştırılmış ve öğrencilerin akademik başarıları üzerinde ÖTBB tekniğinin daha etkili olduğu bulgusuna ulaşılmıştır.

BİK, ÖTBB ve Jigsaw II tekniklerinden elde edilen sonuçlar ve ilgili alanyazında elde edilen bulgular birlikte değerlendirildiğinde genel olarak işbirlikli öğretim tekniklerinin öğrencilerin akademik başarısını sağlamada ve öğrendiklerinin kalıcı olmasında mevcut öğrenme yöntemine kıyasla daha etkili olduğu görülmektedir. İşbirlikli öğrenme tekniklerinin kendi arasındaki karşılaştırmada ise bu çalışmayla uyumlu olarak farklılıkların olmadığı çalışmaların yanı sıra farklılıkların olduğu çalışmaların da olduğu tespit edilmiştir.

$\mathrm{Bu}$ araştırmada; DB grubundaki öğrencilerin motivasyon düzeylerinin ön test sonuçlarına göre diğer gruplarla benzerlik gösterdiği, ön test-son test karşılaştırmasında ölçeğin toplamı ve alt faktörlerinin tamamında puan artışı bulunmasına karşın içsel ve hedef motivasyonu alt faktörlerinde istatistiksel olarak anlamlı farklılık olduğu saptanmıştır. Genel ifadeyle BİOK tekniğinin öğrencilerin motivasyon düzeylerini artırmada olumlu etkisi olduğu ifade edilebilir. Alanyazında BİOK tekniğinin öğrencilerin motivasyonları üzerinde olumlu etkisi olduğunu gösteren bu çalışmayla uyumlu başka çalışmaların olduğu saptanmıştır (Dianawati, 2020; Hayatina ve Fajrina, 2018). Çalışmaların geneline bakıldığında BİOK tekniğinin öğrencilerin motivasyonları üzerinde olumlu etkisi olduğu belirlenmiştir. Ancak alanyazında bu çalışmayla çelişen sonuçların da olduğu belirlenmiştir. Masnaini vd. (2018) tarafından yapılan araştırmada BİK tekniğinin kullanıldığı deney grubu ile geleneksel öğrenme yönteminin kullanıldığı kontrol grubunun motivasyon puanları arasında anlamlı düzeyde farklılık belirlenmemiştir. DB grubunun son test sonuçlarının diğer gruplarla karşılaştırılmasından elde edilen sonuçlara bakıldığında; ölçeğin toplamı ve içsel motivasyon faktöründe DÖ grubuyla arasında DÖ grubu lehine olmak üzere anlamlı farklılık olduğu ancak diğer gruplarla ölçeğin tamamı ve alt faktörlerinde benzer puanlara sahip olduğu görülmektedir. Bu anlamda BİOK tekniğinin Jigsaw II tekniği ve mevcut öğrenme yöntemiyle öğrencilerin motivasyonlarını artırmada benzer etkiye sahip olduğu ancak ÖTBB tekniğinin BİOK tekniğinden daha etkili olduğu yorumunda bulunulabilir.

Yapılan bu araştırmada; DÖ grubunun motivasyon ön test sonuçlarının diğer gruplarla istatistiksel olarak benzer olduğu görülmüştür. Motivasyon ön test-son test karşılaştırmasından elde edilen bulgulara göre; ÖTBB tekniğinin öğrencilerin motivasyon düzeyleri üzerinde ölçeğin tamamı ve tüm alt faktörleri üzerinde istatistiksel olarak anlamlı farklılık oluşturduğu belirlenmiştir. Bu bağlamda ÖTBB tekniğinin öğrencilerin motivasyonları üzerinde olumlu bir etkiye sahip olduğu ifade edilebilir. Alanyazında yapılan çalışmalara bakıldığında bu sonuçları destekleyen başka çalışmaların da olduğu görülmektedir (Gambari, Yusuf ve Thomas, 2015). Araştırma gruplarının son test motivasyon puanlarının karşılaştırılmasından elde edilen bulgulara göre; ölçeğin toplam puanı ile içsel motivasyon faktöründe DÖ lehine anlamlı farklılık olduğu, dışsal motivasyon ve hedef motivasyonu faktörlerinde ise KM grubu arasında DÖ lehine anlamlı farklılık olduğu görülmektedir. Bu doğrultuda öğrencilerin başarılarını artırmada ÖTBB tekniğinin BİK tekniği ve mevcut öğrenme yöntemine göre daha etkili olduğu ancak Jigsaw II tekniğiyle benzer olduğu yorumunda bulunulabilir.

Araştırmanın başlangıcında uygulanan motivasyon ön test uygulamasından elde edilen sonuçlarda DJ grubu öğrencilerinin diğer gruplarla Türkçe dersine yönelik motivasyon düzeylerinin benzerlik gösterdiği belirlenmiştir. Araştırmanın sonunda, ön test-son test karşılaştırmasına göre elde 
edilen bulgular incelendiğinde; Jigsaw II tekniğinin öğrencilerin motivasyon düzeylerini artırmada ölçeğin toplamı, içsel motivasyon, hedef motivasyonu ve motivasyonsuzluk alt faktörlerinde istatistiksel olarak anlamlı farklılık ortaya koyduğu ancak dışsal motivasyon faktöründe puanların artış göstermesine rağmen anlamlı düzeyde bir farklılık bulunmadığı belirlenmiştir. Bu bağlamda genel olarak Jigsaw II tekniğinin öğrencilerin motivasyonları üzerinde olumlu etkisinin olduğu kabul edilebilir. Alanyazında bu çalışmayla uyumlu çalışmaların bulunduğu belirlenmiştir (Melati, 2016; Utami ve Pardjono, 2013). Diğer Jigsaw tekniklerinin öğrencilerin motivasyonları üzerinde olumlu etkisi olduğunu gösteren araştırmaların olduğu da görülmüştür (Rachmah, 2017; Yusnidar, 2018). Alanyazında Jigsaw tekniklerinin diğer yöntemlerle öğrencilerin motivasyonları üzerindeki etkisinin karşılaştırıldığı çalışmalar yer almaktadır. Çatalkaya (2019) yedinci sınıf düzeyinde yaptı̆̆ 1 çalışmasında deney grubunda Jigsaw tekniği ile kontrol grubunda ise $5 \mathrm{E}$ modeli ile dersleri yürütmüştür. Uygulama sonucunda Jigsaw tekniğinin öğrencilerin tutumlarını artırmada 5E modeline göre daha etkili olduğu belirlenmiştir.

$\mathrm{Bu}$ araştırmada; $\mathrm{KM}$ grubunun ön test motivasyon puanlarının diğer gruplarla benzerlik gösterdiği saptanmıştır. Ön test-son test karşılaştırmasına göre elde edilen bulgular incelendiğinde; mevcut öğrenme yönteminin öğrencilerin motivasyon düzeyleri üzerinde anlamlı düzeyde bir etki oluşturmadığı sonucuna ulaşılmıştır. Araştırma gruplarının son test motivasyon puanları karşılaştırıldığında; toplam puan, içsel motivasyon, dışsal motivasyon ve hedef motivasyonu faktörlerinde KM ile DÖ grupları arasında DÖ lehine ve yine toplam puanda KM ile DJ arasında DJ lehine olmak üzere istatistiksel olarak anlamlı farklılık olduğu ancak diğer gruplarla farklılık bulunmadığı belirlenmiştir. Bu doğrultuda mevcut öğrenme yönteminin ÖTBB ve Jigsaw II tekniklerine göre öğrencilerin motivasyonların artırmada daha az etkili olduğu ancak BİOK tekniği ile benzer etki düzeyine sahip olduğu yorumunda bulunulabilir.

Yapılan çalışmalar değerlendirildiğinde; öğrencilerin motivasyon düzeylerinin genel olarak uygulanan işbirlikli tekniklerin neticesinde olumlu olarak etkilendiği görülmüştür. Ayrıca motivasyon ve akademik başarı puanlarının her ikisinin de paralel olarak arttı̆̆ı görülmektedir. Bu bağlamda işbirlikli tekniklerle öğrencilerin motivasyon düzeylerini etkilemesinin onların derslere daha fazla istek duymaları ve konsantre olmalarında etkili olduğu ve bunun neticesinde de akademik başarı puanlarında artış görüldüğü ifade edilebilir. Bu konuda Wolters (1999), öğrencilerin motivasyon düzeylerinin yaratıcılık, araştırma, öğrenme, herhangi bir işe başlama ve devam ettirme, akademik başarı vb. pek çok alanda önemli bir faktör olduğunu, özellikle eğitim ortamlarında etkili olduğunu ifade etmektedir. Ryan ve Deci (2000) de, motivasyonun bireyin tüm yaşamı boyunca oldukça önemli bir faktör olmasına karşın özellikle öğrenme süreçlerindeki akademik başarıları üzerinde belirleyici nitelikte etkisi olduğunu belirtmiştir. Saraçoğlu ve Kâhyaoğlu (2018) ise motivasyonun öğrencilerin sadece akademik becerileri üzerinde değil sorgulama becerileri ve üstbilişsel becerileri üzerinde de olumlu etkisi bulunduğunu söylemektedir. Bu bağlamda akademik başarı ve motivasyonun birbiriyle bağlantılı olduğu ve birbirini etkilediği görülmektedir. Elbetteki yüksek motivasyonun akademik başarı üzerinde etkisi olduğu gibi yüksek düzeydeki akademik başarının da öğrencileri başarılı olmaya ve başarıyı devam ettirme konusundaki motivasyonları üzerinde olumlu etkisinin olduğu düşünülebilir. Uygulanan işbirlikli öğretim tekniklerinin bu konuda hem akademik başarı hem de motivasyon konusunda birlikte etkili olmasının birbirleriyle ilişkili olmalarının sonucu olduğu düşünülebilir.

1. Bu araştırmada işbirlikli öğretim tekniklerinin uygulanmasının öğrencilerin öğrenmeleri üzerinde olumlu etkiye sahip olduğu belirlenmiştir. TÜDÖP hazırlanırken işbirlikli öğretim tekniklerinin kullanılmasına yönelik etkinliklere daha fazla yer verilmelidir. 
2. İşbirlikli öğrenme tekniklerinin Türkçe dersinde uygulanmasına ilişkin öğrenci görüşlerine bakıldığında; bu tekniklerin öğrencilerin sadece akademik başarılarını artırmadığı sosyal ve bilişsel alanlarda da onları desteklediği görülmektedir. Bu doğrultuda diğer derslerin hem öğretilmesi hem de pekiştirilmesinde kullanılması önerilmektedir.

3. Araştırmacıların çalışmalarında bu tür uygulamalı yöntem ve teknikleri tercih ederek geniş bir alanyazın oluşturulması yönünde katkı sunması gereklidir. Özellikle tekniklerin karşılaştırmalı olarak uygulandığı çalışmaların sayısının artmasının önemli olduğu düşünülmektedir.

\section{Kaynaklar}

Açıkgöz, K. Ü. (2004). Aktiföğrenme (13. Baskı). İzmir: Kanyılmaz.

Açıkgöz, K. Ü. (2016). Etkili öğrenme ve öğretme (9. Baskı). İzmir: Biliş.

Ahmad, S. (2015). Improving students skills in translations by using students-teams achievement

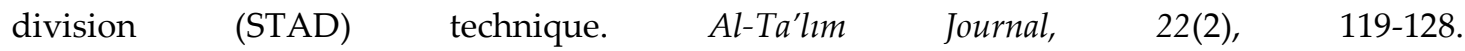
http://dx.doi.org/10.15548/jt.v22i2.121

Akar, M. ve Doymuş, K. (2015). Birlikte öğrenme ve öğrenci takımları başarı bölümlerinin fen bilimleri dersinde akademik başarıya etkisi (Kars il örneği). e-Kafkas Eğitim Araştırmaları Dergisi, 2(3), 7987.

Aksan, D. (2017). Türkçenin gücü (15. Baskı). Ankara: Bilgi.

Aronson, E. (1978). The Jigsaw classroom. Beverly Hills.

Arslan, A. ve Taşgın, A. (2019). Ortaokul öğrencilerine yönelik Türkçe dersine yönelik motivasyon ölçeği geliştirme çalışması. Journal of Computer and Education Research, 7(14), 228-249. https://doi.org/10.18009/jcer.565717

Avcı, S. ve Fer, S. (2004). Birleştirme II tekniği ile oluşturulan işbirliğine dayalı öğrenme ortamının öğrenciler üzerindeki etkisi: Kartal Mesleki Eğitim Merkezi'nde bir durum çalışması. Eğitim ve Bilim, 29(134), 61-74.

Ballantine, J. ve Larres, P. M. (2007). Cooperative learning: A pedagogy to improve students' generic skills? Education And Training, 49(2), 126-137. https://doi.org/10.1108/00400910710739487

Baş, G. (2009). İngilizce dersinde işbirlikli öğrenme yönteminin öğrencilerin erişisi, derse karşı tutumlarına ve öğrenilenlerin kalıcılığına etkisi. Milli Ĕ̆gitim Dergisi, 184, 240-256.

Baydar, A. (2015). Jigsaw ve öğrenci takımları başarı bölümleri yöntemlerinin sosyal bilgiler öğretmen adaylarının epistemolojik inançlarına ve akademik başarılarına etkisi. Doktora Tezi. Atatürk Üniversitesi Eğitim Bilimleri Enstitüsü, Erzurum.

Bayrakçeken, S., Doymuş, K. ve Doğan, A. (2013). İşbirlikli öğrenme modeli ve uygulaması. Ankara: PegemA.

Berlyana, M. D. P. ve Purwaningsih, Y. (2019). Experimentation of STAD and Jigsaw learning models on learning achievements in terms of learning motivation. International Journal of Educational Research Review, 4(4), 517-524. https://doi.org/10.24331/ijere.628311

Borich, G. D. (2014). Etkili öğretim yöntemleri. M. B. Acat (Çev. Ed.). Ankara: Nobel. 
Bozpolat, E. (2012). Türkçe dersinde birleştirilmiş işbirlikli okuma ve kompozisyon teknĭgi ile kullanılan hikâye haritası yönteminin öğrencilerde okuduğunu anlama becerisini geliştirmeye etkisi. Doktora Tezi. Firat Üniversitesi Eğitim Bilimleri Enstitüsü, Elazığ.

Cohen, L., Manion, L. ve Morrison, K. (2000). Research methods in education (6. Bask1). London and New York: Falmer.

Çalıklar, Ş. (2015). Atom kuramlarının öğretiminde öğrencilerin akademik başarıları, epistemolojik inançları ve öğrenmelerinin kalıcılı̆̆ı üzerine öğrenci takımları başarı bölümleri ve takım oyun turnuva yönteminin etkisi. Yüksek Lisans Tezi. Atatürk Üniversitesi Eğitim Bilimleri Enstitüsü, Erzurum.

Çatalkaya, F. B. (2019). Jigsaw I tekniğinin 7. sını öğrencilerinin çevresel farkındalıklarına, iletişim becerilerine ve fen öğrenmeye yönelik motivasyonlarına etkisi. Yüksek Lisans Tezi. Pamukkale Üniversitesi Eğitim Bilimleri Enstitüsü, Denizli.

Çörek, D. (2006). İşbirlikli öğrenmenin Türkçe dersine ilişkin başarı ve derse yönelik tutum üzerindeki etkileri. Doktora Tezi. Dokuz Eylül Üniversitesi Eğitim Bilimleri Enstitüsü, İzmir.

Değer, M. (2010). Sosyal öğrenme kuramı. İ. Yıldırım (Ed.). Eğitim psikolojisi içinde (2. Baskı s. 468-484). Ankara: Anı.

Dianawati, N. (2020). Modifying think pair share (TPS) based on cooperative integrated reading composition (CIRC) to improve students' reading skill and students' motivation. IOSR Journal of Research \& Method in Education (IOSR-JRME, 10(3), 24-32. https://doi.org/10.9790/73881003012432

Doymuş, K., Şimşek, Ü. ve Bayrakçeken, S. (2004). İşbirlikçi öğrenme yönteminin fen bilgisi dersinde akademik başarı ve tutuma etkisi. Türk Fen Ĕ̆itimi Dergisi, 1(2), 103-115.

Ekinci, N. (2011). İşbirlikli öğrenme. Ö. Demirel (Ed.). Ĕ̆itimde yeni yönelimler içinde (5. Baskı, s. 93-112). Ankara: PegemA.

Evcim, H. ve İpek, Ö. F. (2013). Effects of jigsaw II on academic achievement in English prep classes. Procedia-Social and Behavioral 1651-1659. https://doi.org/10.1016/j.sbspro.2013.01.236

Fika, R. (2020). The effectiveness of Jigsaw and STAD (student teams achievement division) cooperative learning model on pharmaceutical mathematics. Journal of Advanced Pharmacy Education $\mathcal{E}$ Research, 10(2), 147-158.

Gambari, A. I. ve Yusuf, M. O. (2017). Relative effectiveness of computer-supported Jigsaw II, STAD and TAI cooperative learning strategies on performance, attitude, and retention of secondary school students in physics. Journal of Peer Learning, 10(6), 76-94.

Gambrari, I. A., Yusuf, M. O. ve Thomas, D. A. (2015). Effects of computer-assisted STAD, LTM and ICI cooperative learning strategies on nigerian secondary school students' achievement, gender and motivation in physics. Journal of Education and Practice, 6(19), 16-28.

Genlott, A. A. ve Grönlund, ̊̊. (2013). Improving literacy skills through learning reading by writing: The iWTR method presented and tested.Computers $\mathcal{E}$ Education, 67, 98-104. https://doi.org/10.1016/j.compedu.2013.03.007

Gonzales, W. D. W. ve Torres, P. L. (2015). Looking at CIRC through quantitative lenses: Can it improve the reading comprehension of filipino esl learners? Online Submission, 15, 67-98. 
Gözütok, D. (2007). Öğretim ilke ve yöntemleri (2. Baskı). Ankara: Ekinoks.

Güreş, G. (2008). Kubaşık okuma yazma dinleme ve konuşma tekniğinin ilköğretim dördüncü sımıföğrencilerinin akademik başarılarına ve İngilizce dersine ilişkin tutumlarma etkisi. Yüksek Lisans Tezi. Adnan Menderes Üniversitesi Sosyal Bilimler Enstitüsü, Aydın.

Hayatina, M. ve Fajrina, S. A. (2018). Cooperative integrated reading composition to improve pupils' reading comprehension achievement and motivation. Journal of Research, Policy \& Practice of Teachers and Teacher Education, 8(2), 29-37. https://doi.org/10.37134/jrpptte.vol8.no2.4.2018

İlgaz, S. ve Çelen, A. (2017) Ayrılıp birleşme ve ÖTBB (Öğrenci Takımları Başarı Bölümleri) yöntemlerinin sosyal bilgiler akademik başarıya etkisinin karşılaştırılması. Journal of Computer and Education Research, 5(10), 174-193. https://doi.org/10.18009/jcer.315923

Jalilifar, A. (2010). The effect of cooperative learning techniques on college students' reading comprehension. System, 38(1), 96-108. https://doi.org/10.1016/j.system.2009.12.009

Johnson, R. T. ve Johnson, D. W. (1990). Social skills for successful group work. Educational Leadership, 47(4), 29-33.

Johnson D. W. ve Johnson R. T. (1999). Making cooperative learning work. Theory into Practice, 38(2), 6773. https://doi.org/10.1080/00405849909543834

Johnson, D. W. ve Johnson, R. T. (2002). Learning together and alone: Overview and meta-analysis. Asia Pacific Journal of Education, 22(1), 95-105. https://doi.org/10.1080/0218879020220110

Johnson, D. W., Johnson, R. T. ve Holubec, E. J. (1994). The new cirefcs of leaming, cooperation in the classroom. Virginia: Association for Süpervision and Curriculum Development.

Juliana, M. ve Surya, E. (2017). An analysis of Jigsaw cooperative effectiveness to improve the selfconfidence and learning result of vocational high school students. International Journal of Advance Research and Innovative Ideas in Education, 3(2), 3519-3526.

Karafkan, M. A. ve Aghazadeh, Z. (2015). Investigating the effects of group investigation (GI) and cooperative integrated reading and comprehension (CIRC) as the cooperative learning techniques on learner's reading comprehension. International Journal of Applied Linguistics and English Literature, 4(6), 8-15. https://doi.org/10.7575/aiac.ijalel.v.4n.6p.8

Karasar, N. (2014). Bilimsel araştırma yöntemi (26. Baskı). Ankara: Nobel.

Kartal, Ş. ve Özbek, R. (2016). İşbirlikli öğrenme tekniklerinden ÖTBB tekniğiyle işlenen İngilizce dersine ilişkin öğrenci görüşleri. The Journal of International Lingual Social and Educational Sciences, 2(2), 85-106.

Khuzaemah, E. ve Herawati, L. (2017). Pembelajaran menulis esai menggunakan model cooperative integrated reading and composition (CIRC) berbasis life skills. Indonesian Language Education and Literature, 2(2), 148-162. http://dx.doi.org/10.24235/ileal.v2i2.1360

Kim, D. (2018). A Study on the influence of Korean middle school students' relationship through science class applying STAD cooperative learning. Journal of Technology and Science Education, 8(4), 291309. https://doi.org/10.3926/jotse.407

Koç, Y., Yildiz, E., Çaliklar, S. ve Simsek, U. (2016). Effect of Jigsaw II, reading-writing-presentation, and computer animations on the teaching of Light Unit. Educational Research and Reviews, 11(20), 1906-1917. https://doi.org/10.5897/ERR2016.2861 
Komisyon. (2014). Öğretim ilke ve yöntemleri (1. Baskı). Ankara: Anı.

Lee, R. M. ve Robbins, S. B. (1998). The relationship between social connectedness and anxiety, selfesteem, and social identity. Journal of Counseling Psychology, 45, 338-345. https://doi.org/10.1037/0022-0167.45.3.338

Masnaini, Copriady, J. ve Osman, K. (2018). Cooperative integrated reading and composition (CIRC) with mind mapping strategy and its effects on chemistry achievement and motivation. AsiaPacific Forum on Science Learning \& Teaching, 19(1), 1-18.

Melati, E. (2016). The effect of Jigsaw II toward learning motivation and reading comprehension at the second grade of English students in stkıp dharma baktı. Research of Applied Science and Education, 8(2), 40-58. http://dx.doi.org/10.22216/jit.2014.v8i2.211

Miller, P. H. (1997). Theories of developmental psychology (3. Bask1). NewYork: W. H. Freeman.

Nurwanti, N., Asrifan, A. ve Haedar, H. (2019). The application of cooperative learning: Jigsaw II technique in improving students' reading comprehension of expository text. Journal of Advanced English Studies, 2(1), 31-40. http://dx.doi.org/10.47354/jaes.v2i1.52

Ocak, G. ve Kü̧̈ükilhan, B. U. S. (2014). İşbirliğine dayalı öğrenci takımları-başarı bölümleri (ÖTBB) tekniğinin sosyal bilgiler dersindeki akademik başarıya ve kalıcılığa etkisi. e-Uluslararası Ĕ̆gitim Araştırmaları Dergisi, 5(4), 17-40.

Putri, D. S. A. (2013). The use of Jigsaw II technique and still pictures combination to improve students' vocabulary mastery. Journal of English Language Teaching, 2(2), 1-11. https://doi.org/10.15294/elt.v2i2.2387

Rachmah, D. N. (2017). Effects of Jigsaw learning method on students' self-efficacy and motivation to learn. Journal of Educational, Health and Community Psychology, 6(3), 1-9. http://dx.doi.org/10.12928/jehcp.v6i3.8314

Ryan, R. M. ve Deci, E. L. (2000). Intrinsic and extrinsic motivations: Classic definitions and new directions. Contemporary Educational Psychology, 25, 54-67. https://doi.org/10.1006/ceps.1999.1020

Saraçoğlu, M. ve Kahyaoğlu, M. (2018). Ortaokul öğrencilerinin bilimsel sorgulama becerileri algılarının, merak, motivasyon ve tutum açısından incelenmesi. Journal of Computer and Education Research, 6(12), 358-376. https://doi.org/10.18009/jcer.472673

Senemoğlu, N. (2007). Gelişim öğrenme ve öğretim (Düzenlenmiş Yeni Baskı). Ankara: Gönül.

Sharan, S. (1999). Cooperative learning and the teacher. S. Sharan (Ed.). Handbook of cooperative learning methods içinde (2. Bask1, s. 336-348). London: Praeger.

Slavin, R. E. (1987). Cooperative learning: Student teams, what research says to teachers (2. Bask1). Washington, DC: Professional Library National Education Association.

Slavin, R. E. (1990). Research on cooperative learning: Consensus and controversy. Educational leadership, 47(4), 52-54.

Slavin, R. E. (1999). Students teams-achievement divisions. S. Sharan (Ed.). Handbook of cooperative learning methods içinde (2. Bask1, s. 3-19). London: Praeger. 
Tabiolo, J. L. ve Rogayan, V. (2019). Enhancing students' science achievement through Jigsaw II strategy. Journal of Science Learning, 3(1), 29-35. https://doi.org/10.17509/jsl.v3i1.17680

Tarım, K. ve Akdeniz, F. (2008). The effects of cooperative learning on Turkish elementary students' mathematics achievement and attitude towards mathematics using TAI and STAD methods. Educ Stud Math, 67, 77-91. https://doi.org/10.1007/s10649-007-9088-y

Tiantong, M. ve Teemuangsai, S. (2013). Student team achievement divisions (STAD) technique through the moodle to enhance learning achievement. International Education Studies, 6(4), 85-92. http://dx.doi.org/10.5539/ies.v6n4p85

Utami, P. ve Pardjono, P. (2013). Perbedaan Jigsaw II dan GI terhadap pemahaman konsep dan pemecahan masalah masalah pada kompetensi mendiagnosis permasalahan pengoperasian PC dan Peripheral ditinjau dari motivasi belajar. Jurnal Pendidikan Vokasi, 3(2), 234-250. https://doi.org/10.21831/jpv.v3i2.1604

Watson, S. B. (1992). The essential elements of cooperative learning. The American Biology Teacher, 54(2), 84-86. https://doi.org/10.2307/4449413

Wolters, C. A. (1999). The relation between high school students' motivational regulation and their use of learning strategies, effort, and classroom performance. Learning and Individual Differences, 11(3), 281-300. https://doi.org/10.1016/S1041-6080(99)80004-1

Yaman, B. (1999). Birleştirilmiş işbirlikli okuma ve yazma tekniğinin beşinci sımıföğrencilerinin Türkçe dersinde okuduğunu anlamaya yönelik akademik başarılarn ile Türkçe dersine ilişkin tutumları üzerindeki etkisi. Yüksek Lisans Tezi. Çukurova Üniversitesi Eğitim Bilimleri Enstitüsü, Adana.

Yılar, R. (2016). İşbirlikli öğrenme uygulamalarından Jigsaw (II) tekniğinin sözlü anlatım dersine yönelik tutuma etkisi. Bayburt Eğitim Fakültesi Dergisi, 7(1), 129-140.

Yılar, M., Şimşek, U., Topkaya, Y. ve Balkaya, İ. (2015). İşbirlikli öğrenme yöntemlerinin sosyal bilgiler öğretmenliği lisans öğrencilerinin akademik başarılarına etkileri. Uşak Üniversitesi Sosyal Bilimler Dergisi, 8(4), 297-318.

Yılmaz, A. (2001). İşbirliğine dayalı (Kubaşık) öğrenme yönteminin yükseköğretim sınıflarında kullanılması. Kuram ve Uygulamada Ĕ̆itim Yönetimi, 28, 593-612.

Yurdabakan, İ. ve Cihanoğlu, M. O. (2009). Öz ve akran değerlendirmenin uygulandığg işbirlikli okuma ve kompozisyon tekniğinin başarı, tutum ve strateji kullanım düzeylerine etkisi. Dokuz Eylül Üniversitesi Sosyal Bilimler Enstitüsü Dergisi, 11(4), 105-123

Yusnidar, Y. (2018). Meningkatkan motivasi dan aktivitas belajar sıswa di kelas VII. C MTsN Paninjauan dengan menggunakan model pembelajaran kooperatif tipe Jigsaw. Bıoedukası, 9(2), 173-180. http://dx.doi.org/10.24127/bioedukasi.v9i2.1613

Zarei, A. A. (2012). The effects of STAD and CIRC on L2 reading comprehension and vocabulary learning. Frontiers of Language and Teaching, 3(5), 161-173.

\section{Yazarların Katkı Oranı Beyanı}

Bu makalede birinci yazarın katkı oranı \%60 iken ikinci yazarınki \%40'tır. Çalışma doktora tezinden üretildiği için çalışma süreçleri her iki yazar tarafından birlikte planlanmış uygulama ve yazımı ilk yazar tarafından yapılmıştır. Kontroller ise ikinci yazar tarafıundan yapılmıştır. 


\section{Destek ve Teşekkür Beyanı}

Araştırmanın birinci yazarının doktora tezine ve dolayısıyla da bu çalışmaya katkılarından dolayı TÜBİTAK'a teşekkürlerimizi sunarız.

\section{Çatışma Beyanı}

Araştırma ile ilgili diğer kişi ve kurumlarla herhangi bir kişisel ve finansal çıkar çatışması yoktur.

\section{Etik Bildirim}

Bu çalışma doktora tezinden üretilmiş olup 01.01.2020 tarihinden önce yapıldığından etik kurul kararı zorunluluğu yoktur. 